\title{
ESTATISTICA
}

\section{Censo Escolar}

(1)

O sistema educacional brasileiro atende a mais de 57 milhões de alunos em todos os níveis e modalidades de ensino e é administrado por uma complexa rede que envolve a esfera federal, 27 Secretarias Estaduais de Educação e quase seis mil prefeituras municipais, além do setor privado. Diante desse quadro, ganha destaque fundamental a existência de informações e dados quantitativos que auxiliem o gerenciamento de todo à, sistema e possibilitem a elaboração de diagnósticos precisos que subsidiem a formulação de políticas.

Embora o sistema educacional brasileiro tenha se ampliado enormemente nos últimos anos e desempenhe um papel primordial na consolidação do processo democrático, há um consenso de que ele ainda precisa aperfeiçoar-se, especialmente no que se refere à sua qualidade.

Nesse sentido, as estatísticas educacionais, em conjunto com os processos de avaliação, justificam-se, principalmente quando elas fornecem informações confiáveis e úteis, possibilitando que o processo de decisão de políticas e programas se enriqueça com o aprendizado institucional acumulado. A avaliação, ao ser capaz de acompanhar o desempenho das políticas educacionais, fornece elementos para a formulação de políticas que visem atenuar as deficiências do sistema, promovam o seu aprimoramento e contribuam para ampliar a sua eqüidade.

O Inep, por meio da Diretoria de Estatísticas da Educação Básica (Seec), coordena, em âmbito nacional, a realização do Censo Escolar. Esse levantamento produz dados estatísticos sobre as condições de infra-estrutura dos estabelecimentos escolares, oferta de matrículas, rendimento e movimento dos alunos e qualificação do corpo docente.
A coleta dos dados e o processamento das informações são operacionalizados pelas Secretarias de Educação das unidades da Federação, sob a coordenação da Seec/Inep. A coordenação desse processo envolve desde o levantamento das necessidades das Secretarias Estaduais e dos órgãos que compõem o MEC, para a elaboração do instrumento de coleta, a confecção e a distribuição dos formulários, 0 acompanhamento da coleta e da digitação, a assistência técnica durante o processo de crítica de consistência, até o recebimento dos bancos de dados dos Estados, para processamento e análise dos resultados.

Os dados relativos à matrícula de alunos na rede pública de ensino fundamental apurados pelo Censo Escolar são uma exigência legal para a redistribuição automática dos recursos do Fundo de Manutenção e Desenvolvimento do Ensino Fundamental e de Valorização do Magistério (Fundef), assim como, também, servem de parâmetro para a aplicação de diversos programas governamentais. Desde 1997, o Inep mantém um sistema de controle de qualidade que permite monitorar a confiabilidade das informações produzidas pelo Censo Escolar.

Nesta publicação, são apresentados, de forma sintética, dados relativos à evolução da matrícula (1991-2002), englobando a educação infantil, classes de alfabetização, ensino fundamental, ensino médio, educação especial, educação de jovens e adultos e educação superior. Para a obtenção de mais informações e de indicadores mais detalhados, pode ser acessado o sítio do Inep (www.inep.gov.br). 


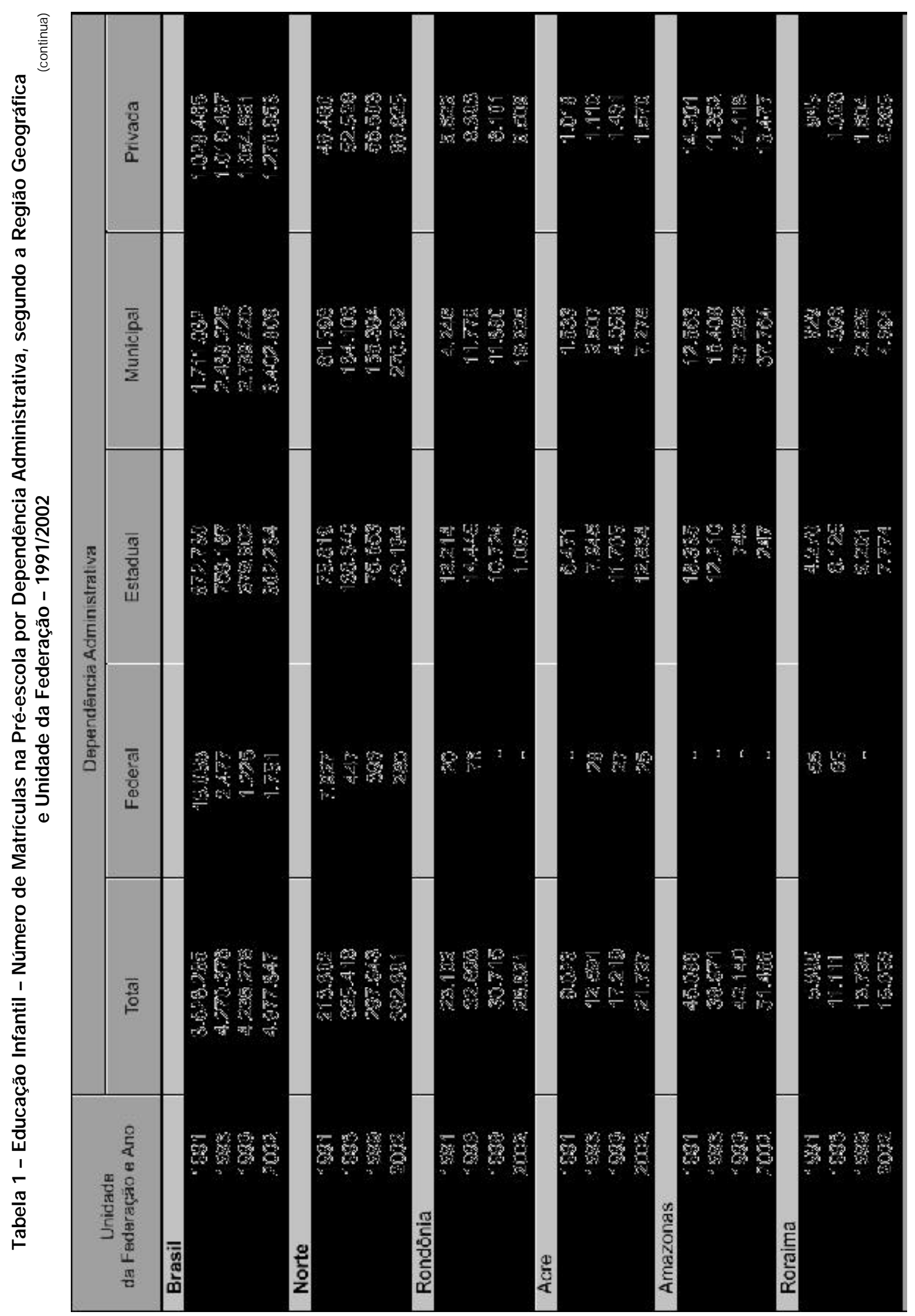




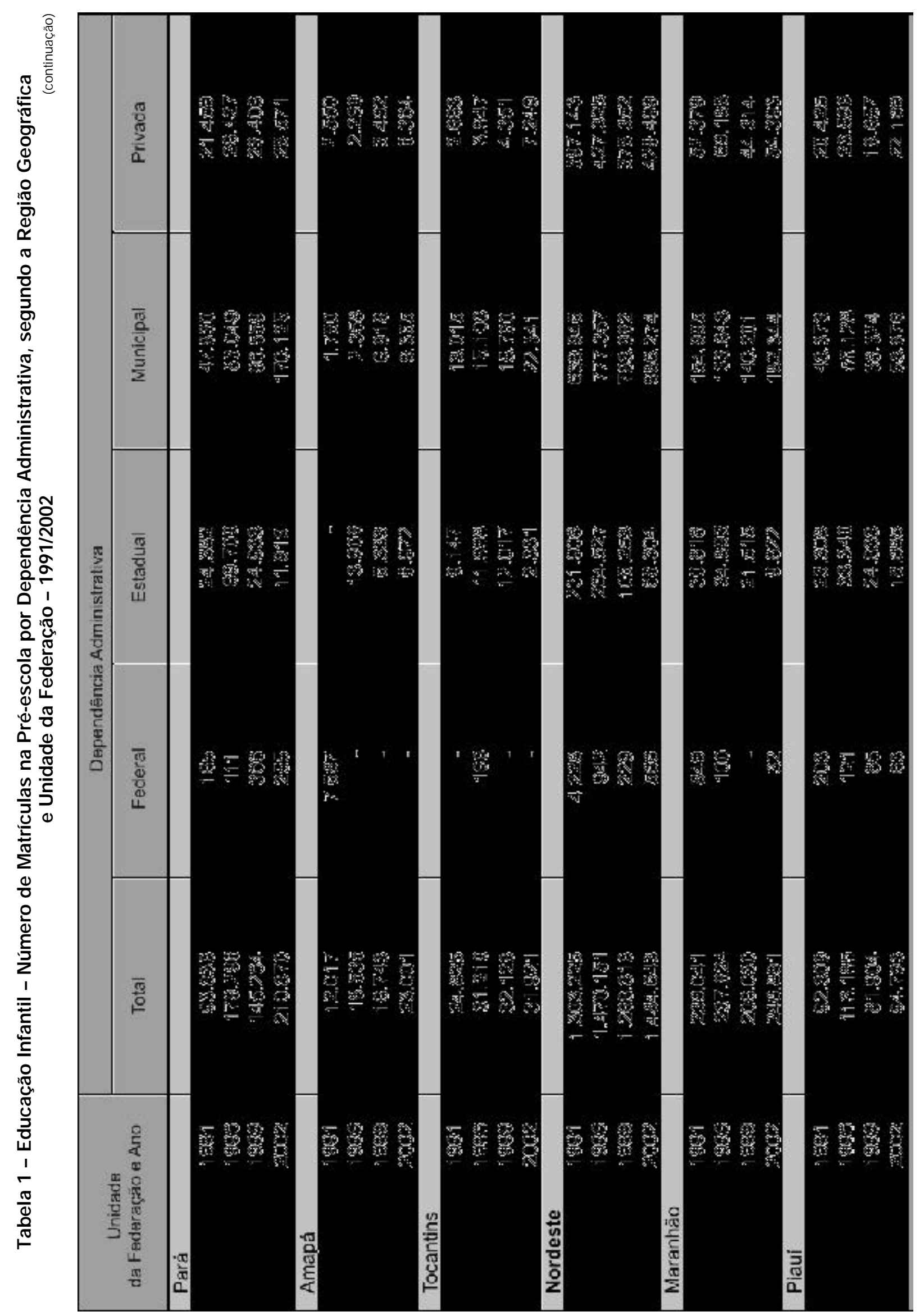




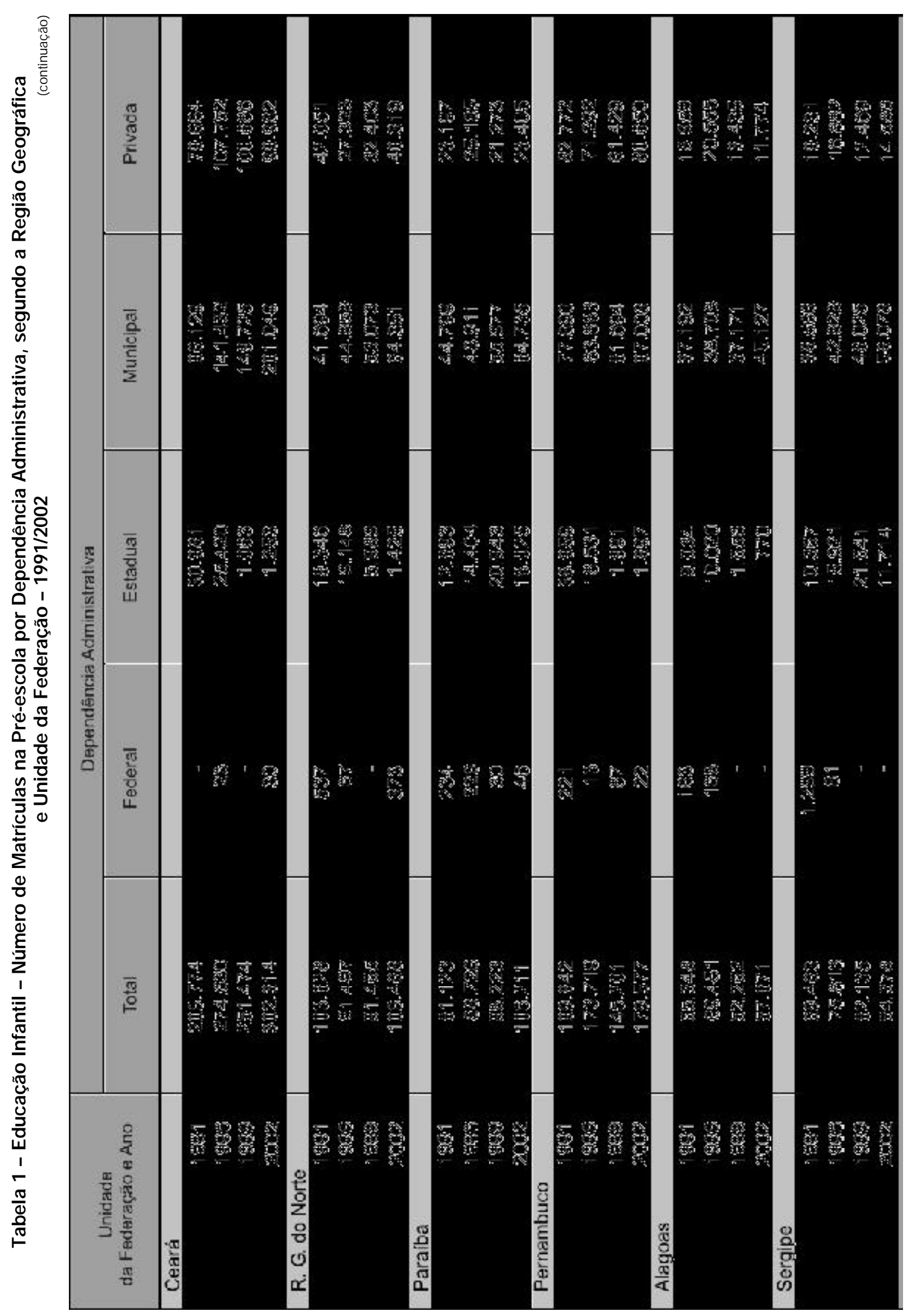




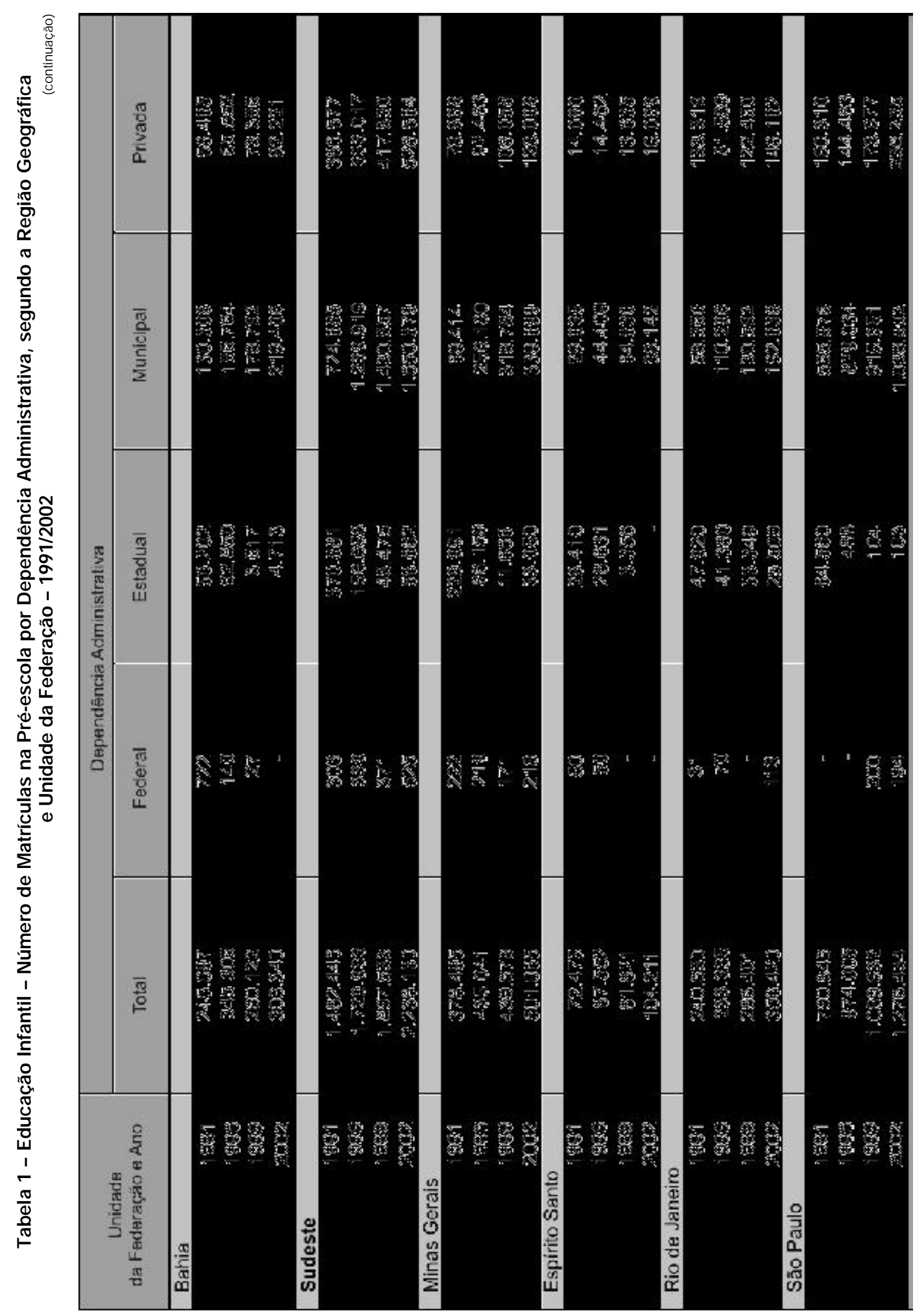




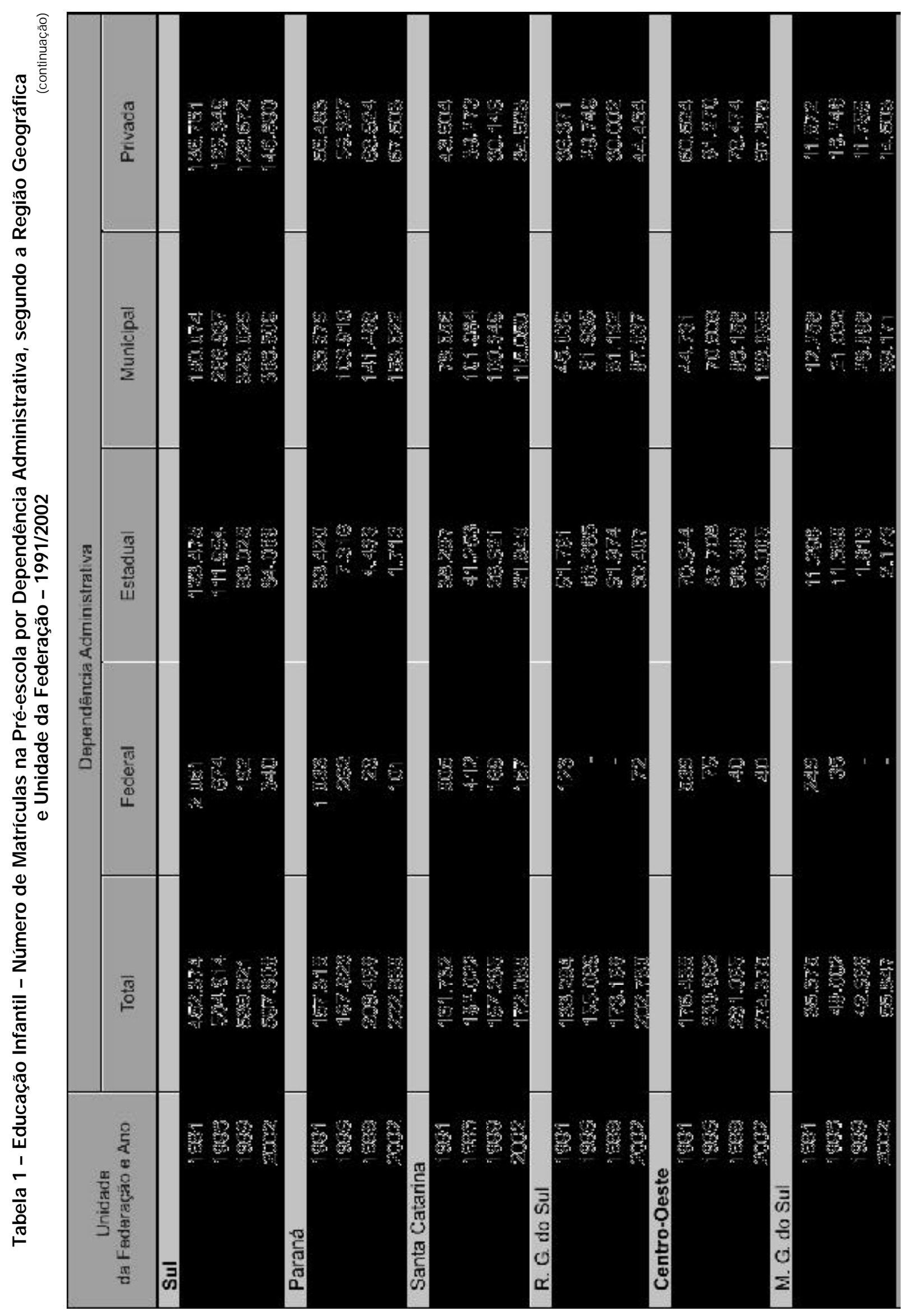




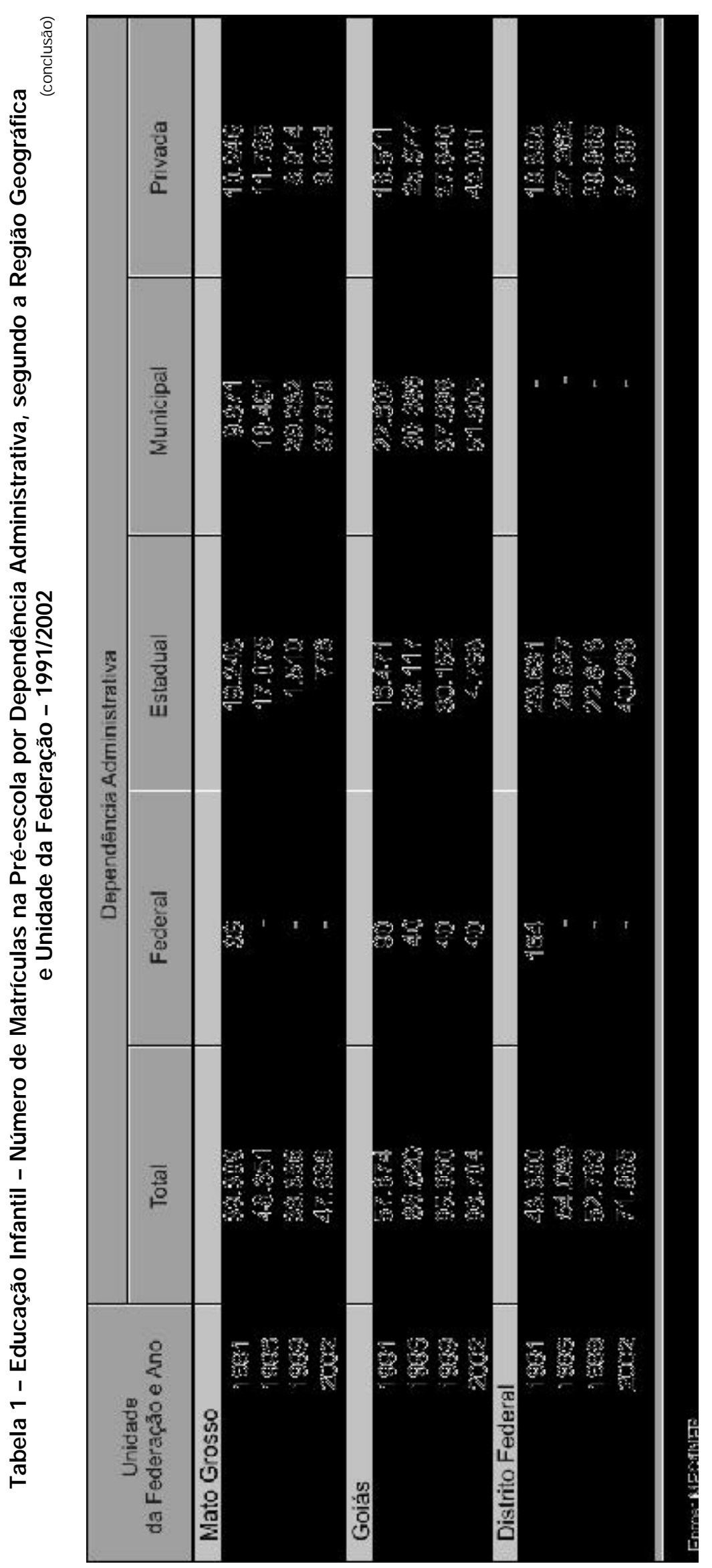

R. bras. Est. pedag., Brasília, v. 81, n. 199, p. 525-567, set./dez. 2000. 


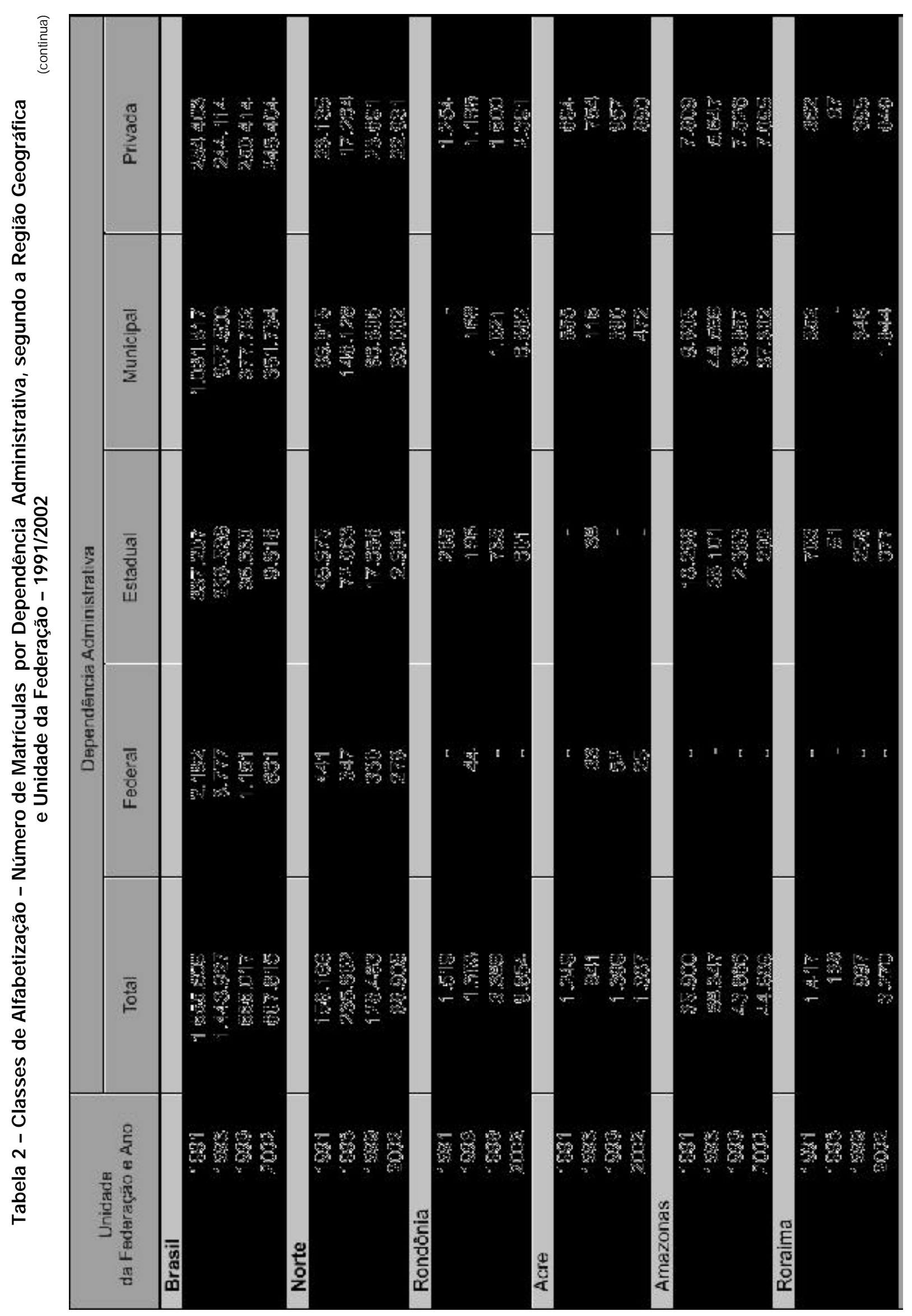




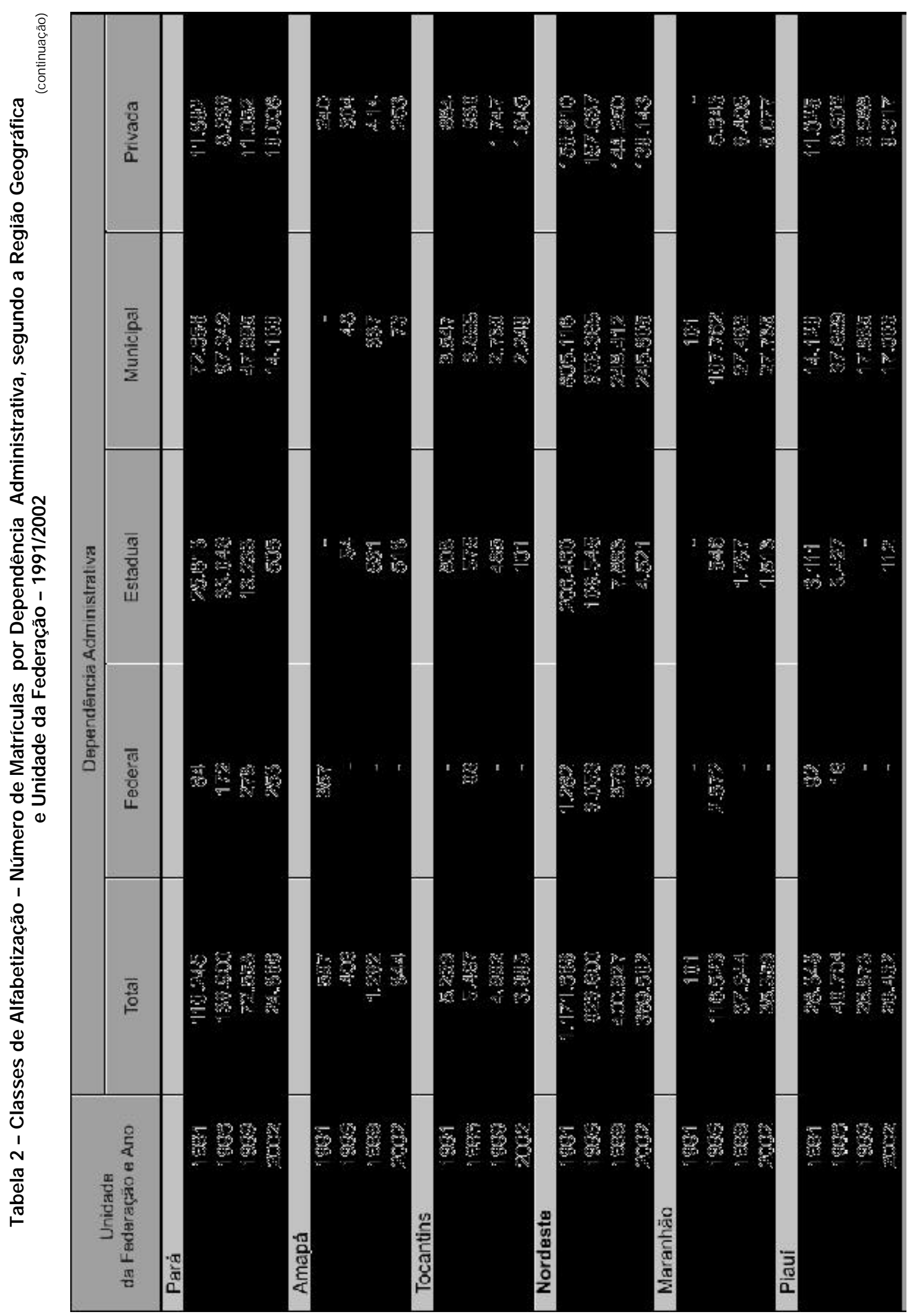




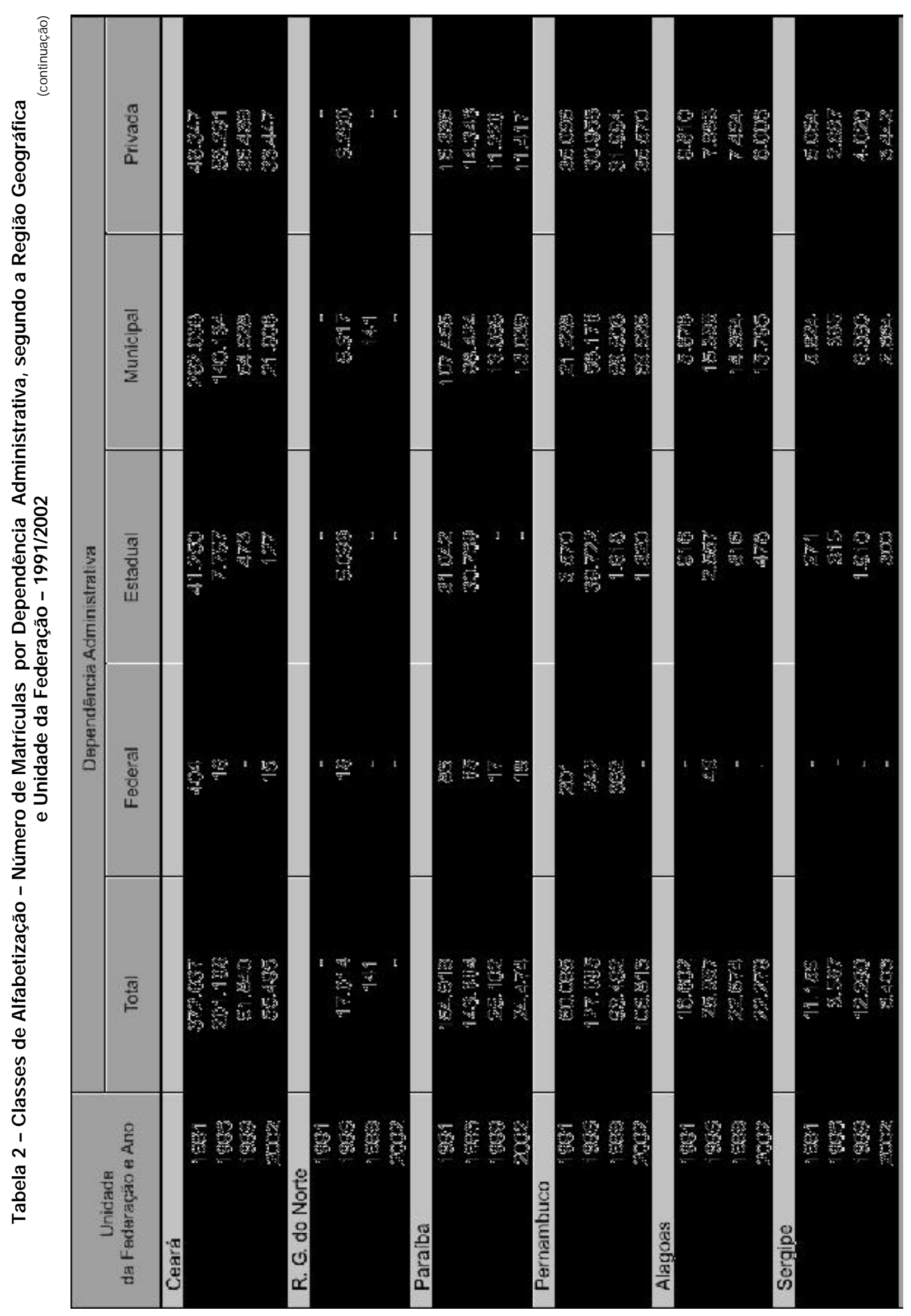




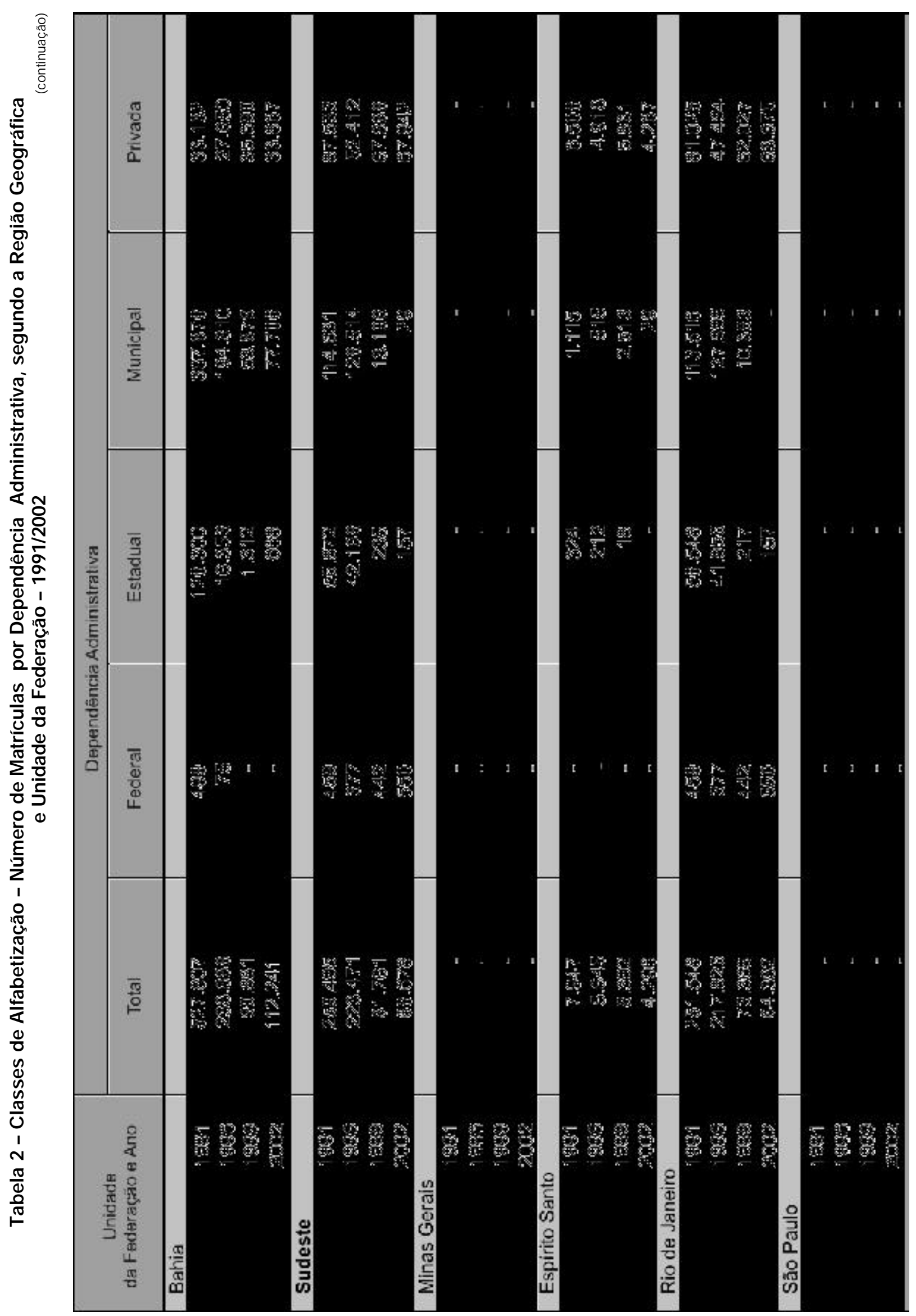




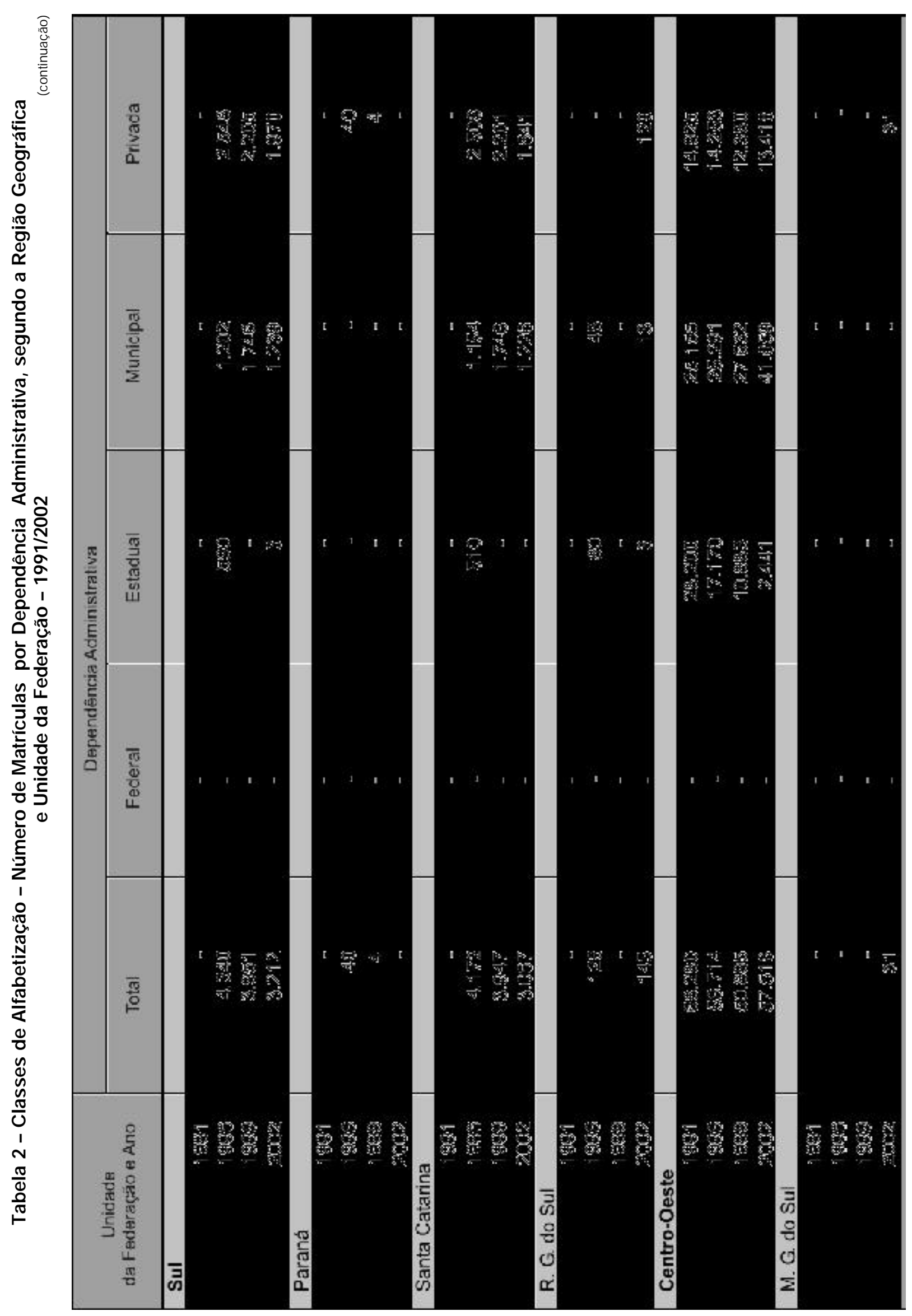




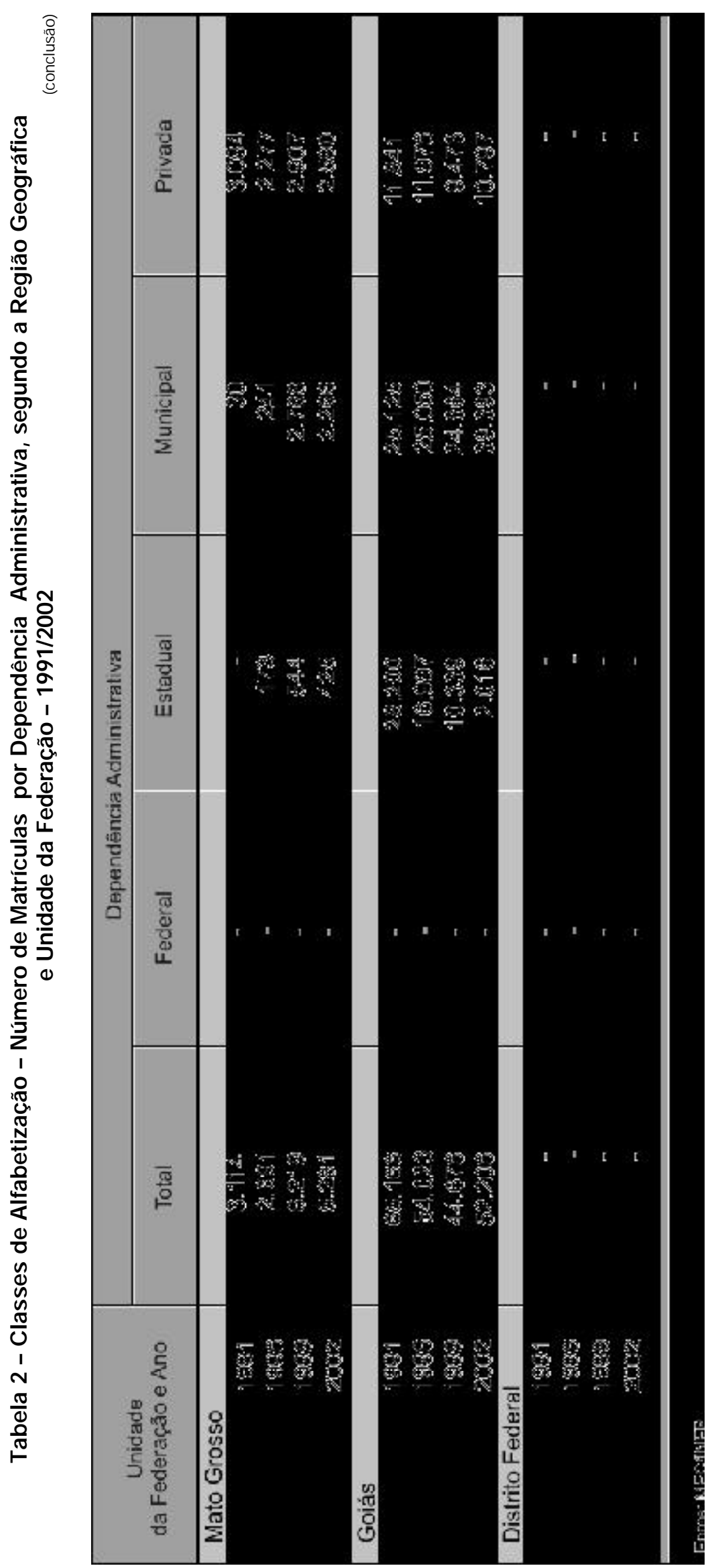

R. bras. Est. pedag., Brasília, v. 81, n. 199, p. 525-567, set.dez. 2000. 


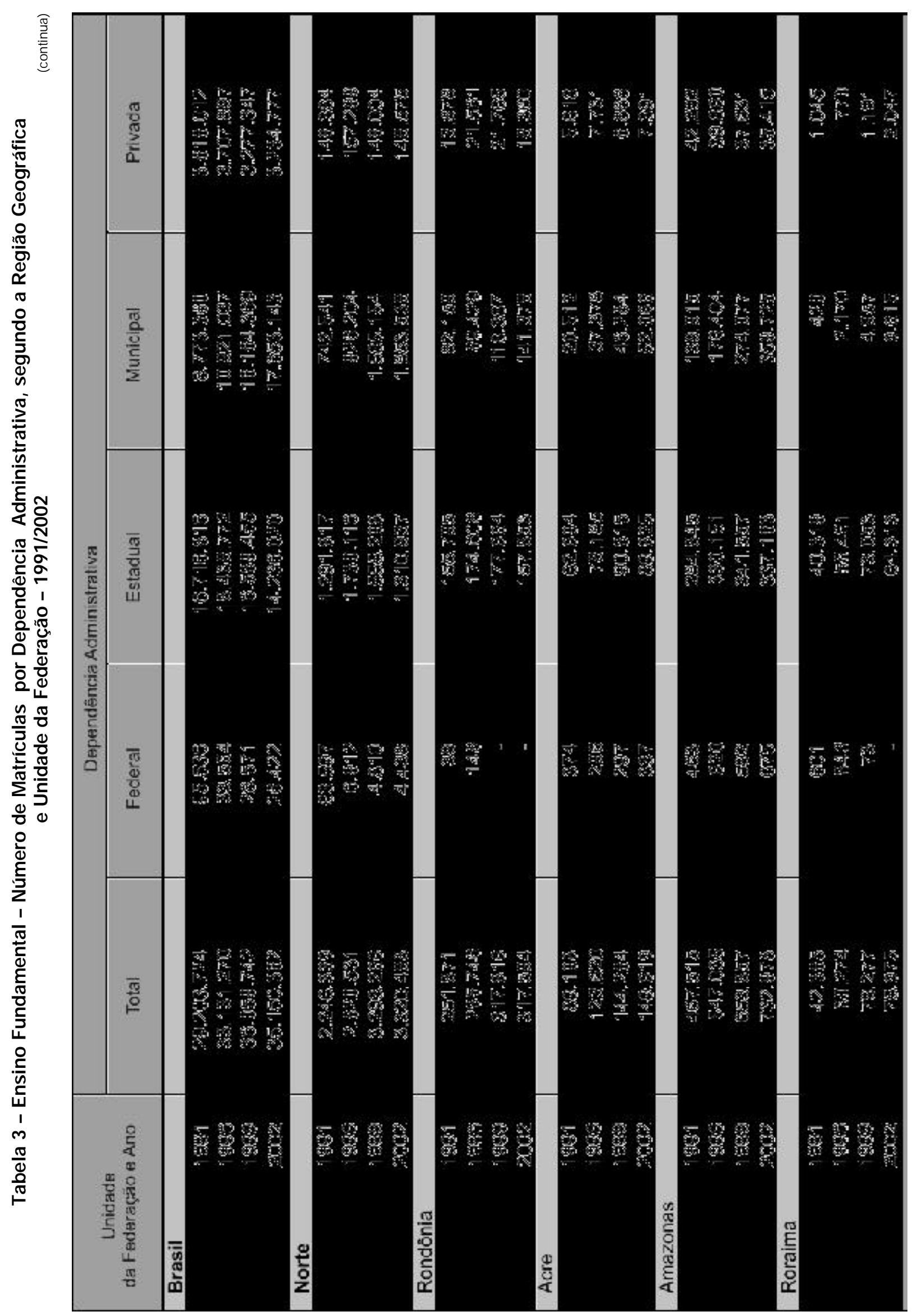




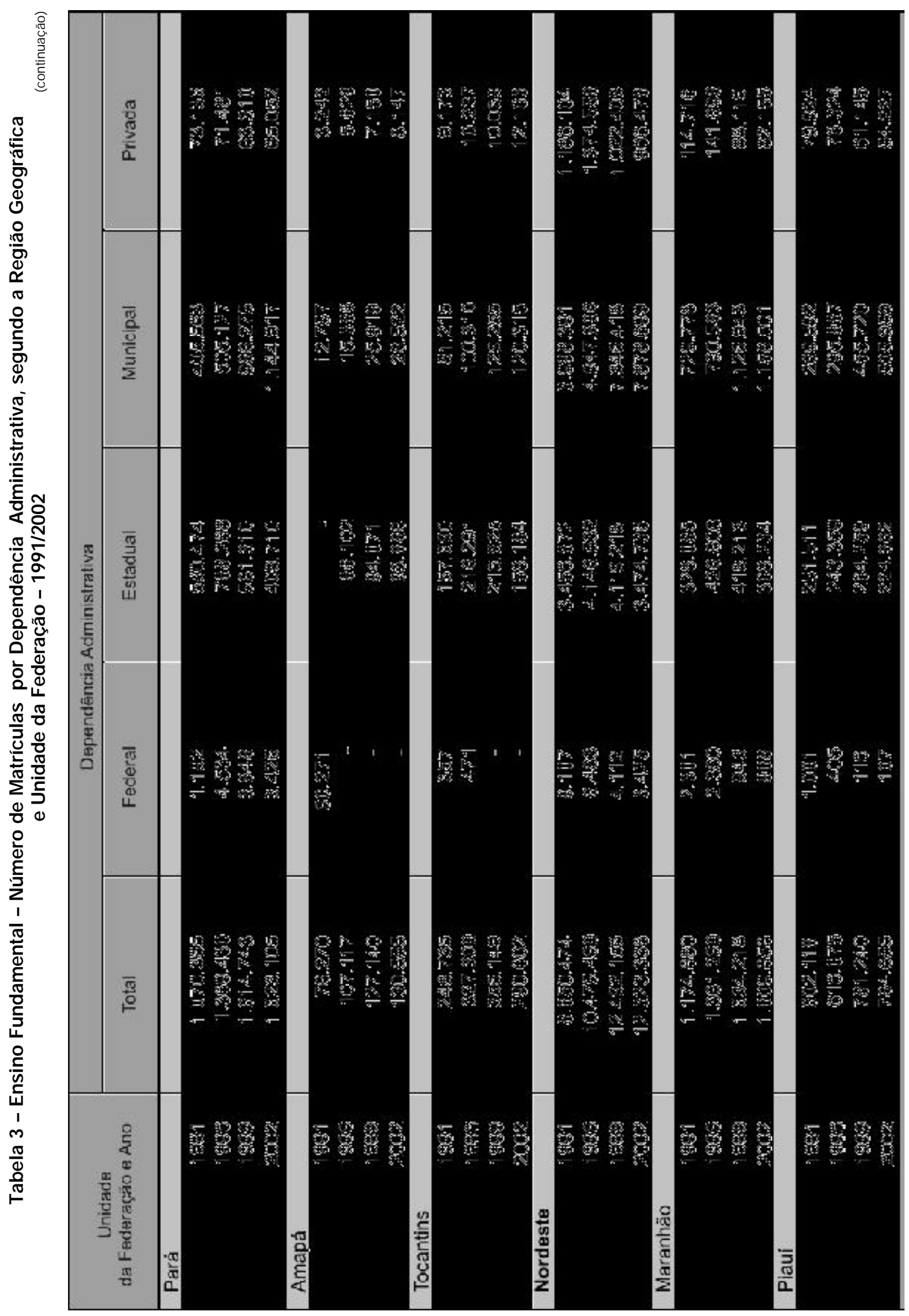




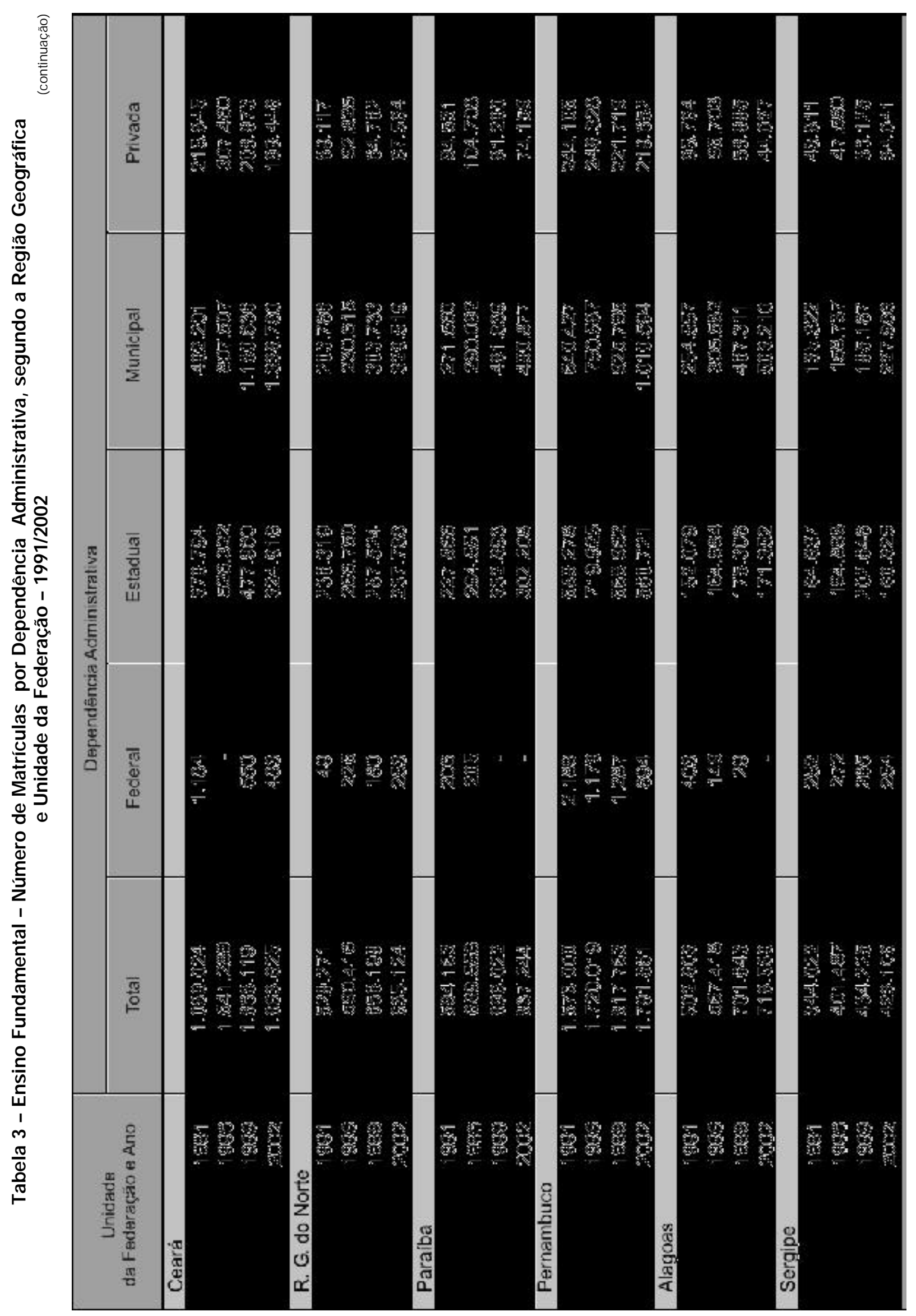




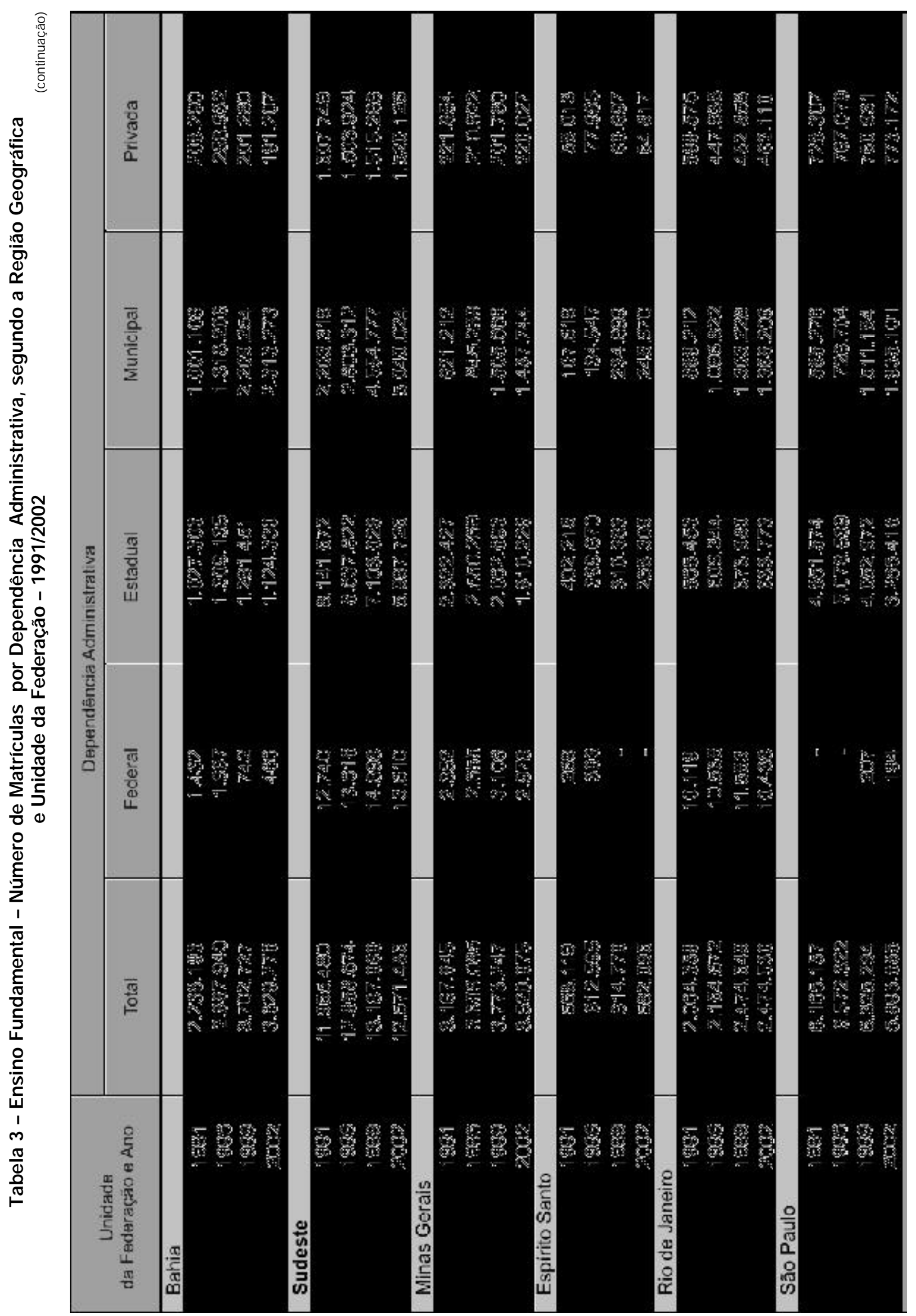




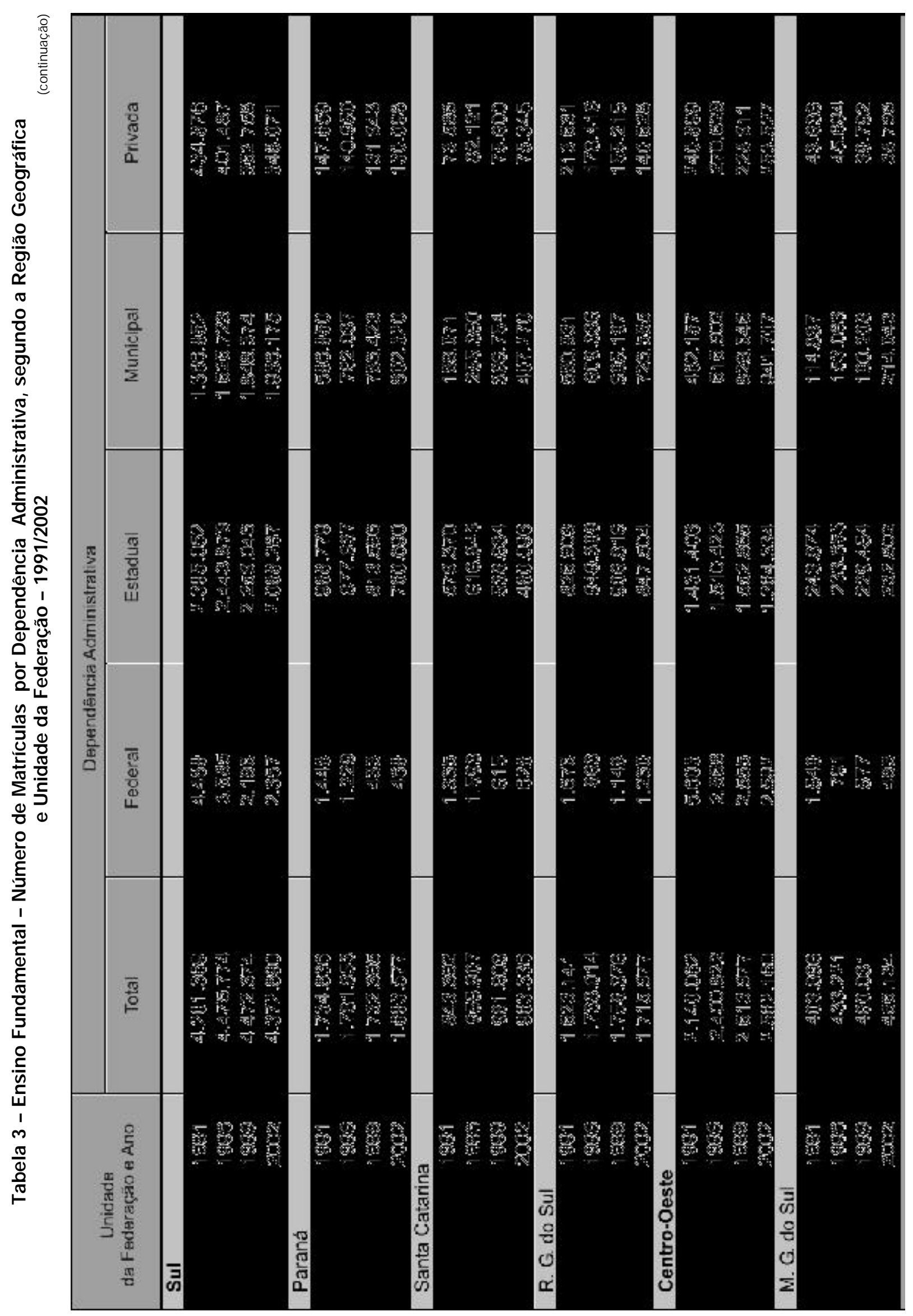




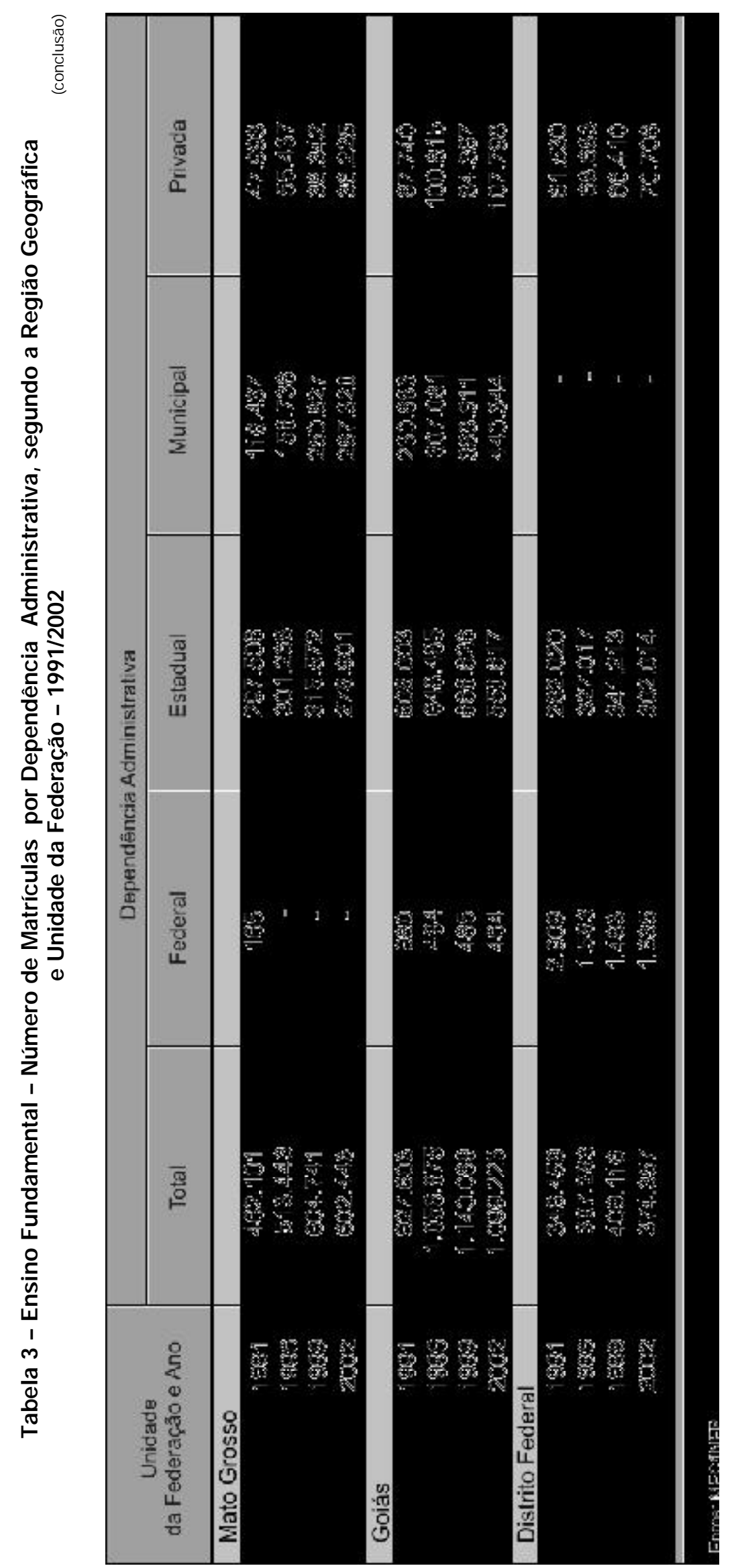

R. bras. Est. pedag., Brasília, v. 81, n. 199, p. 525-567, set./dez. 2000. 


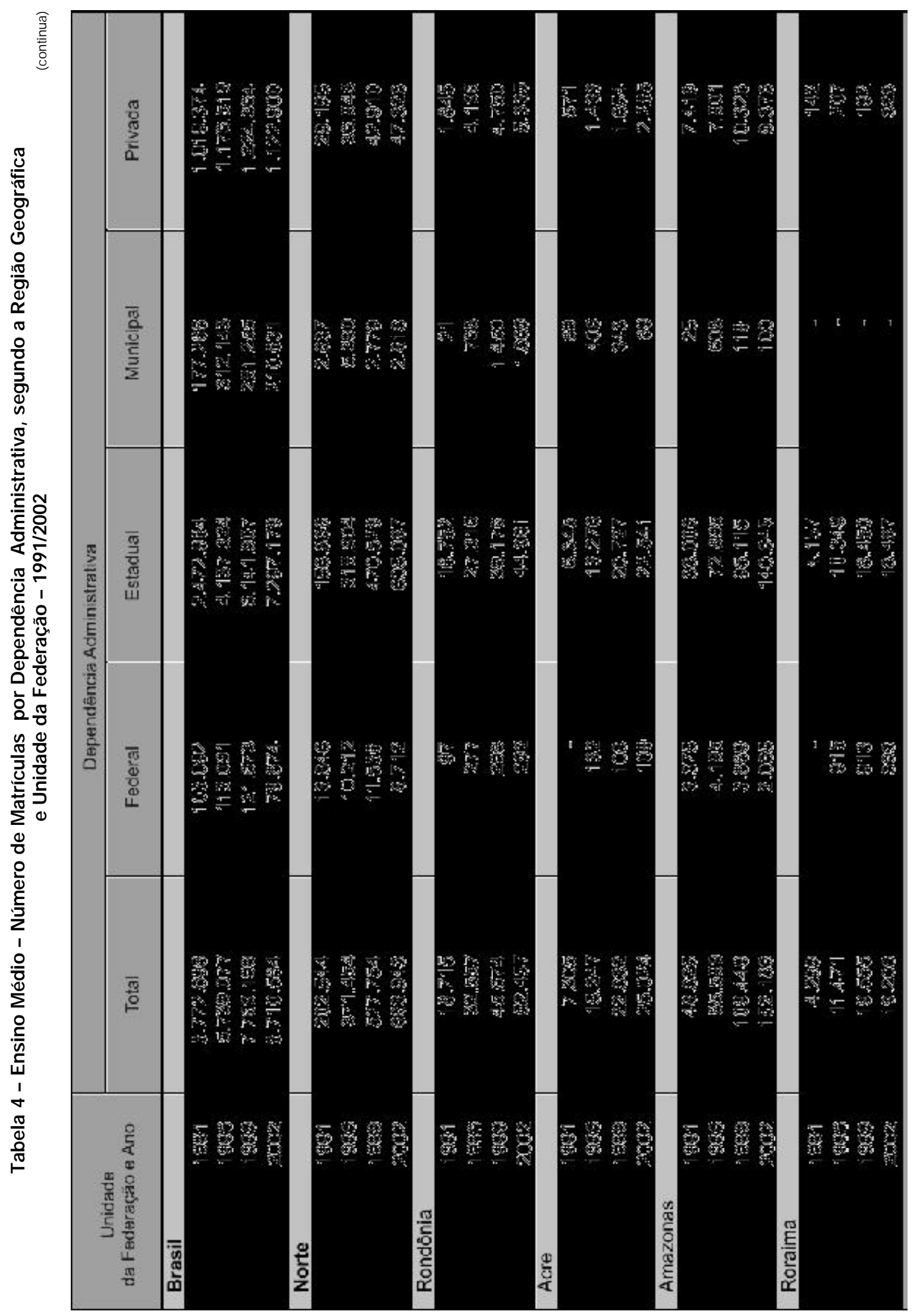




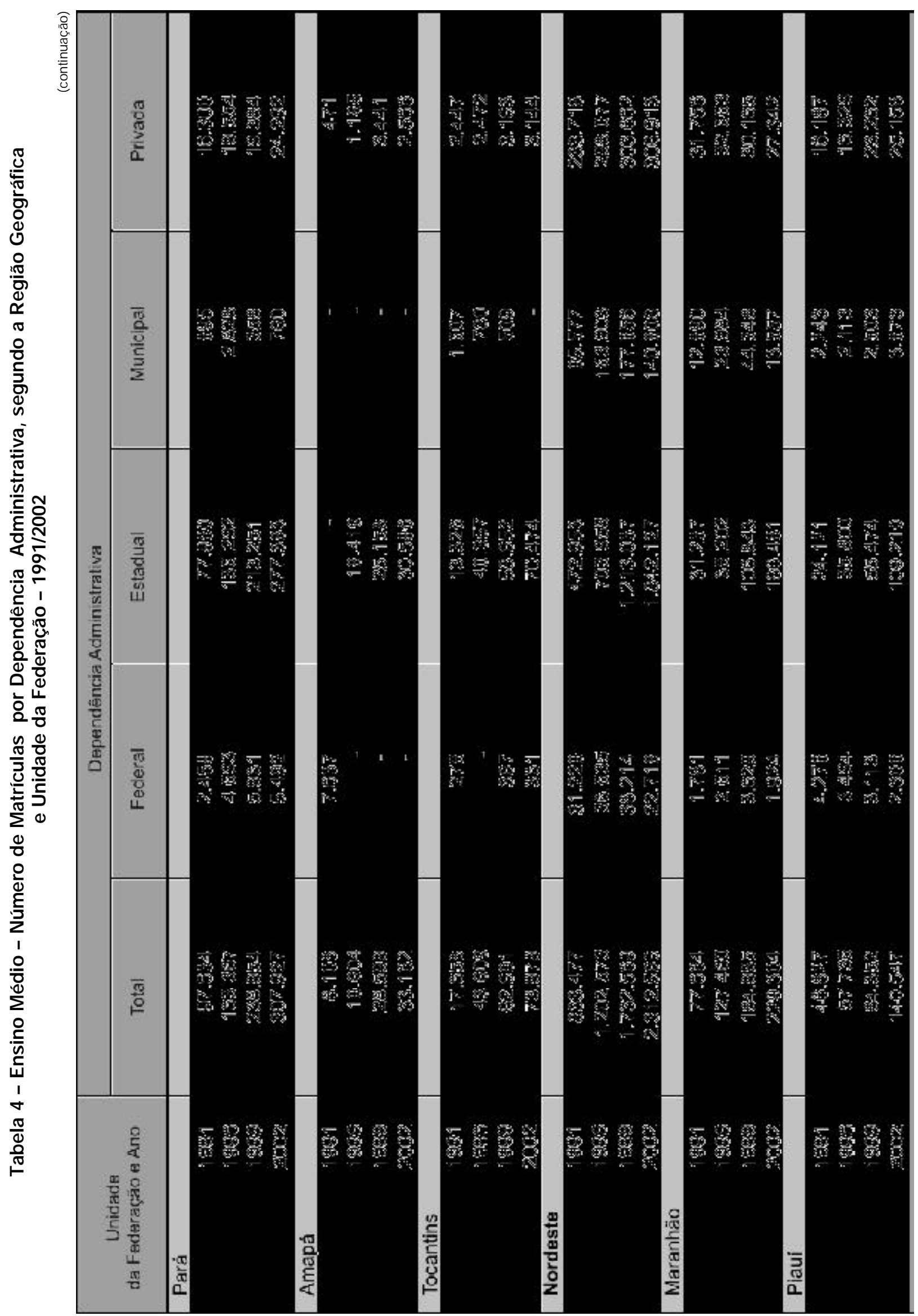




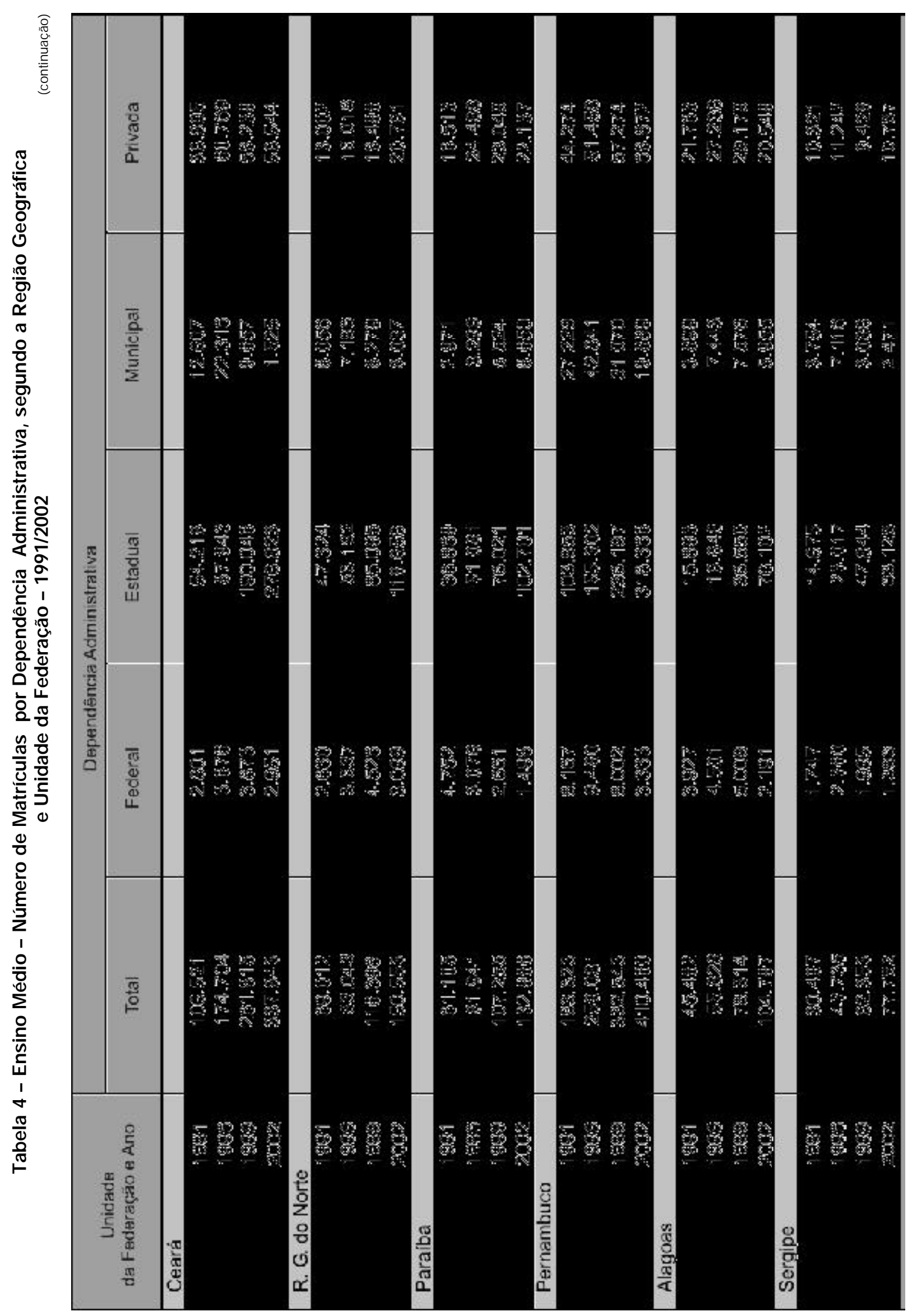




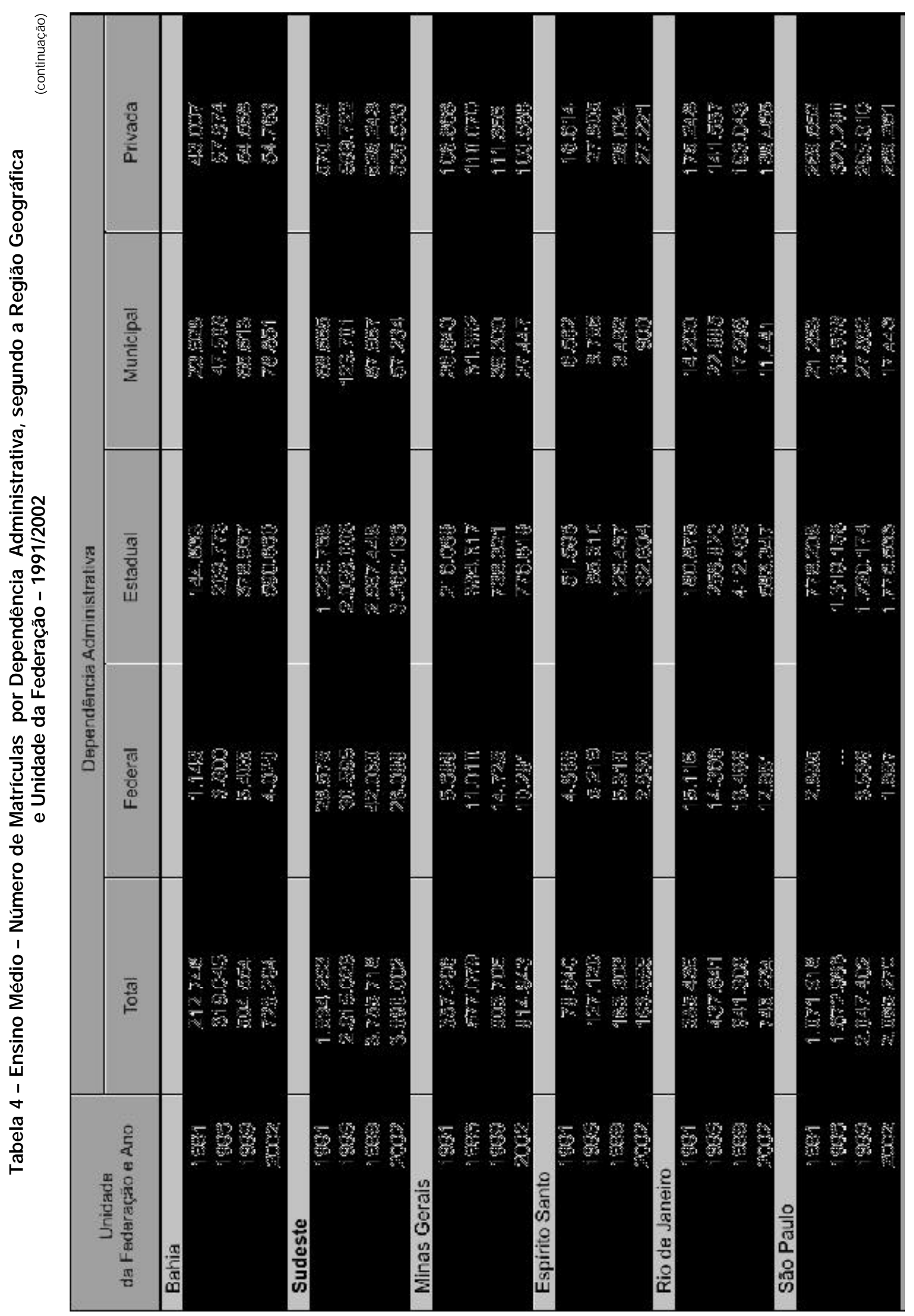




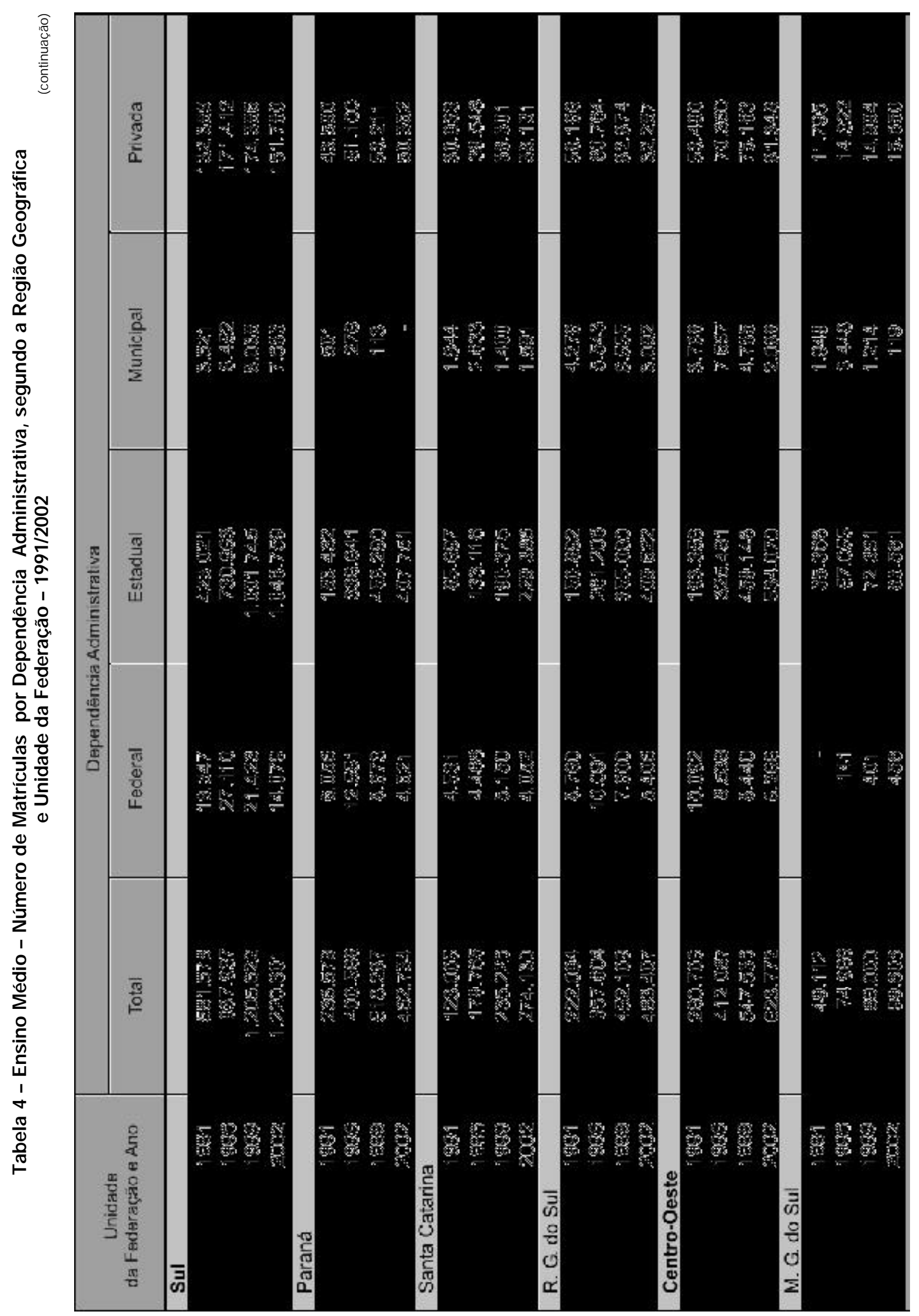




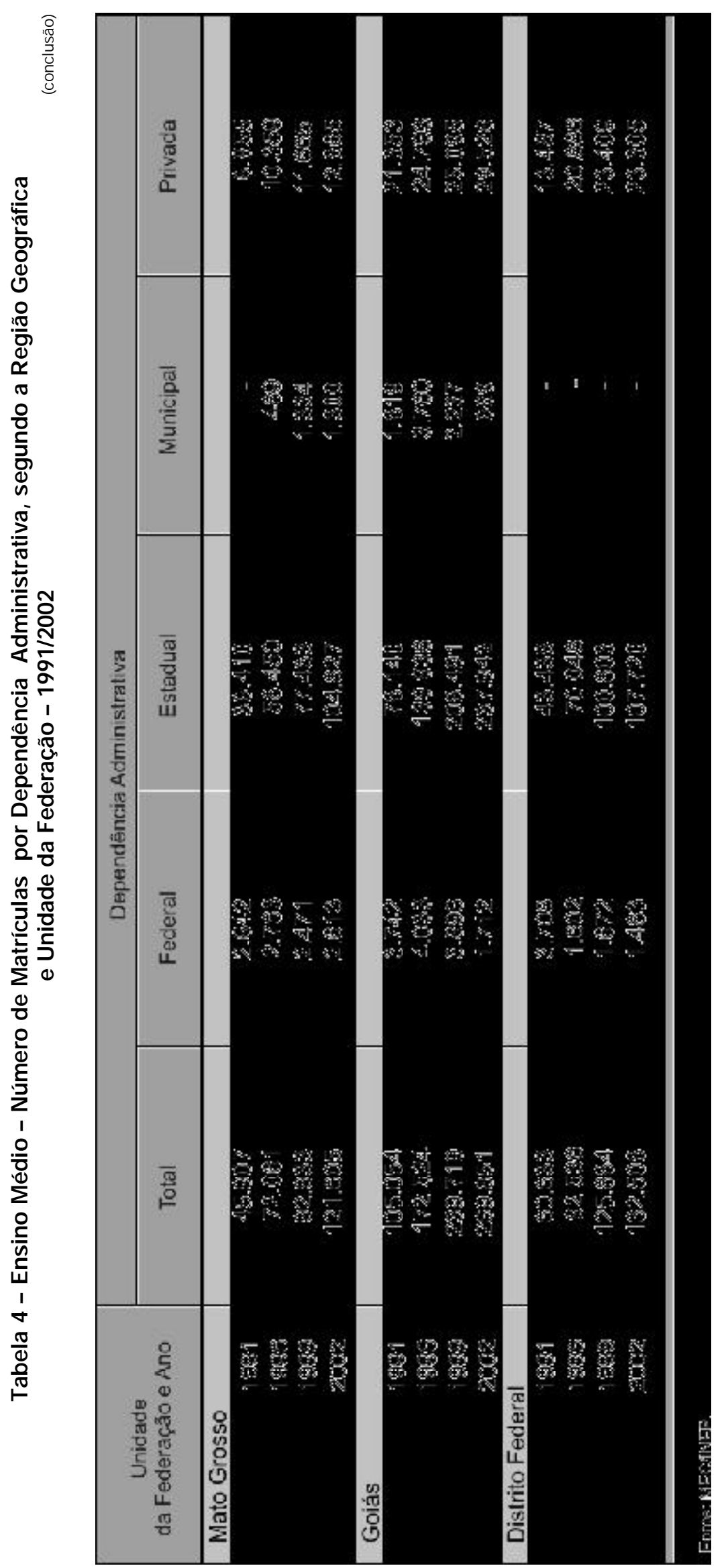

R. bras. Est. pedag., Brasília, v. 81, n. 199, p. 525-567, set./dez. 2000. 


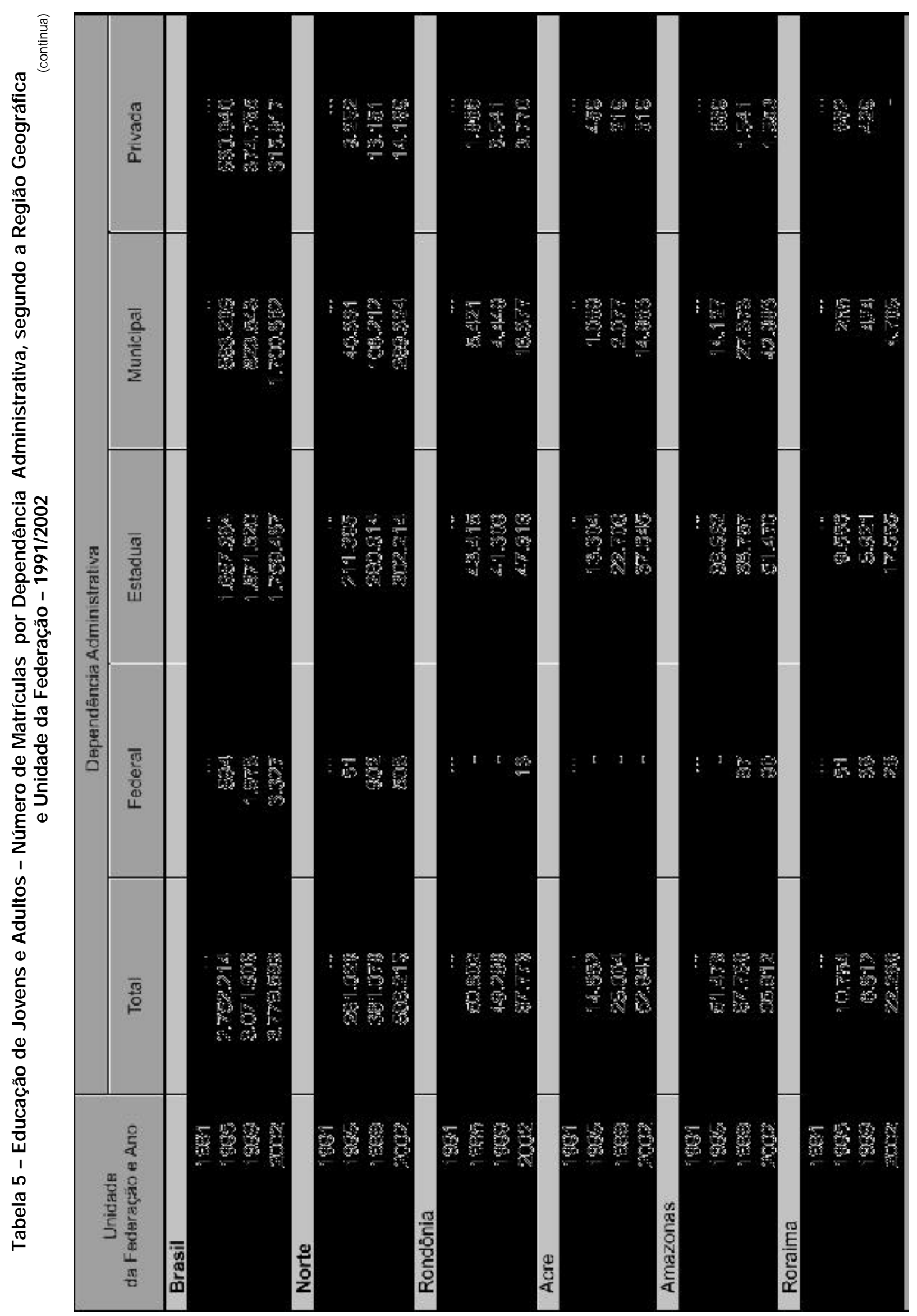




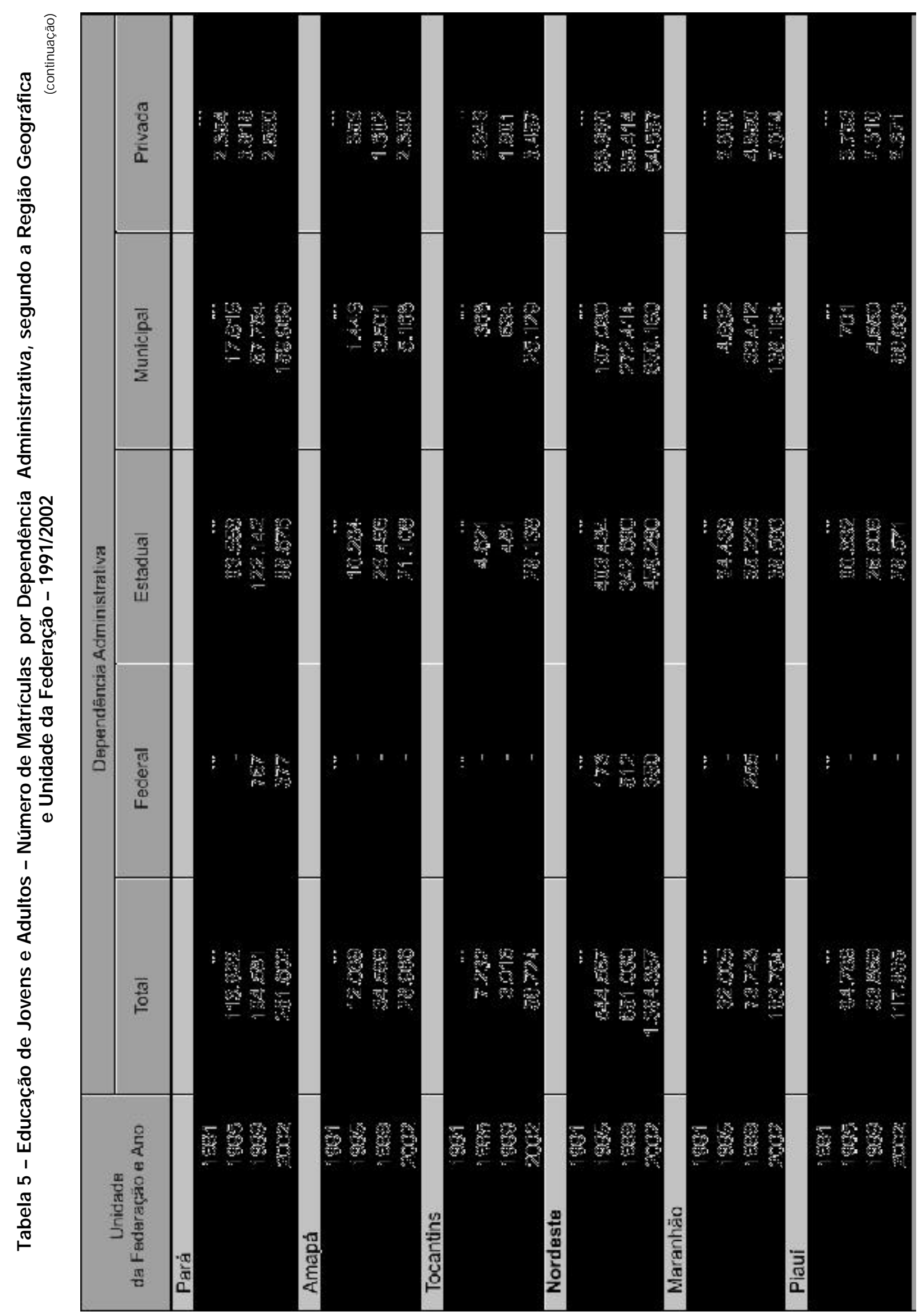




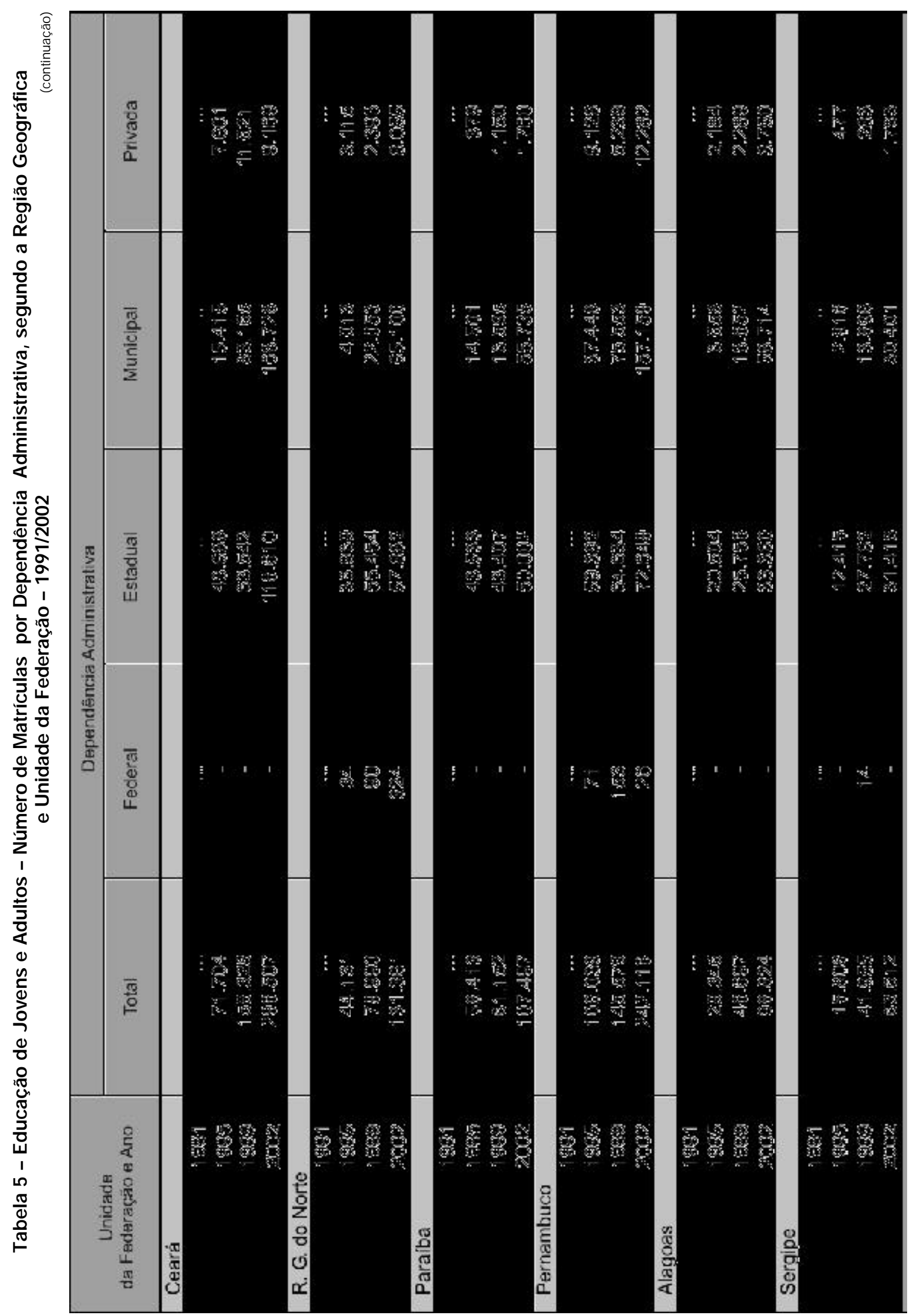




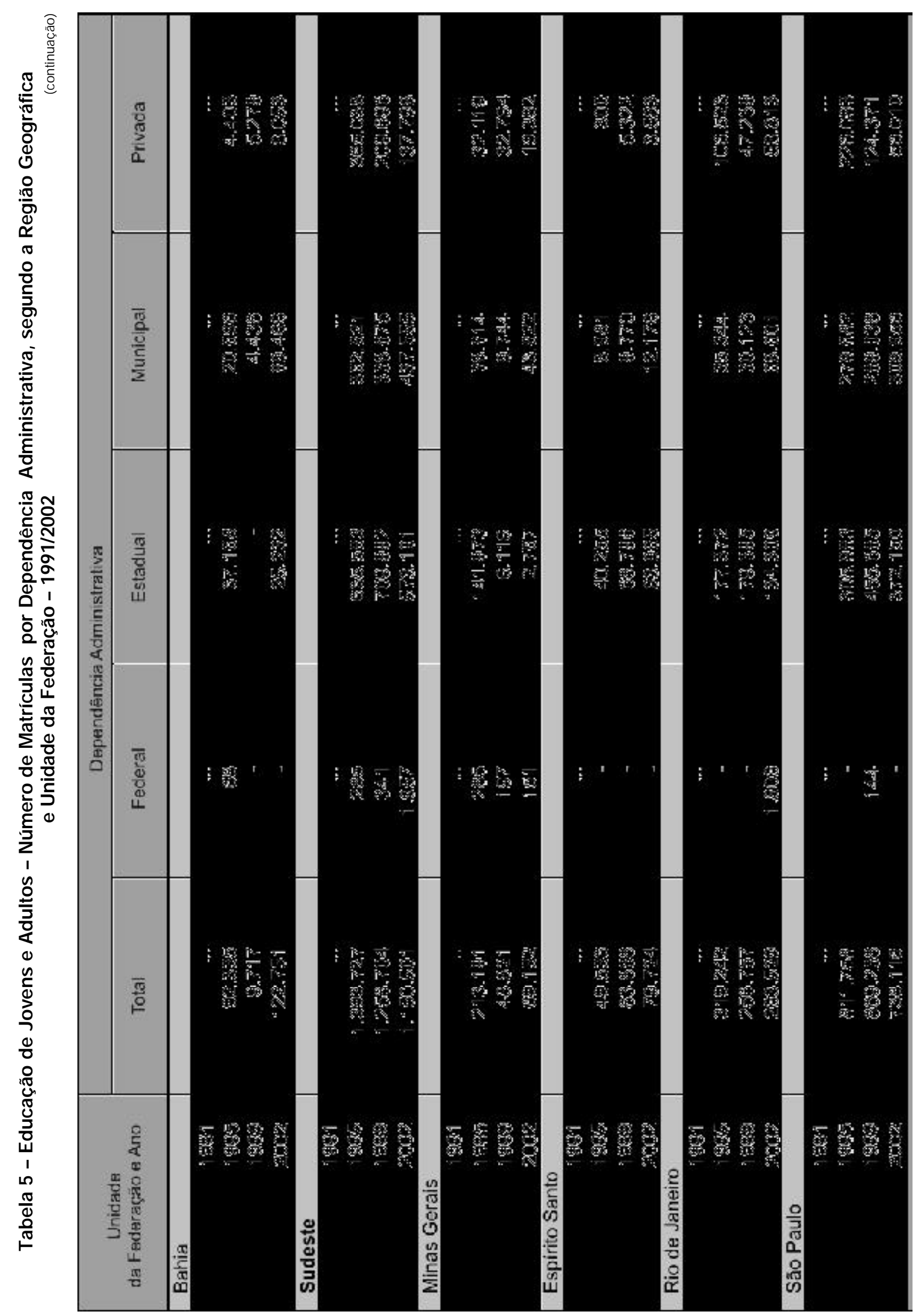




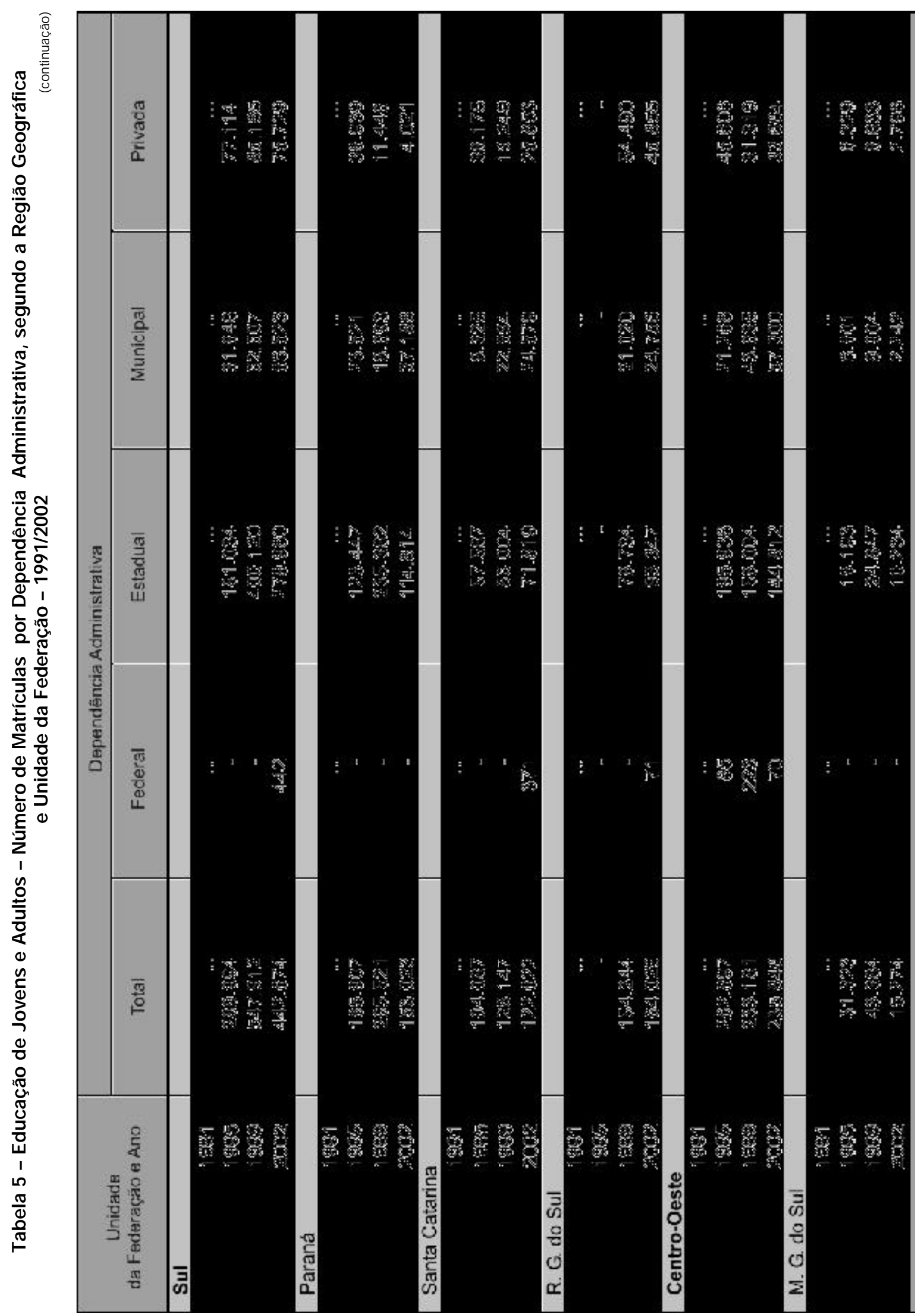




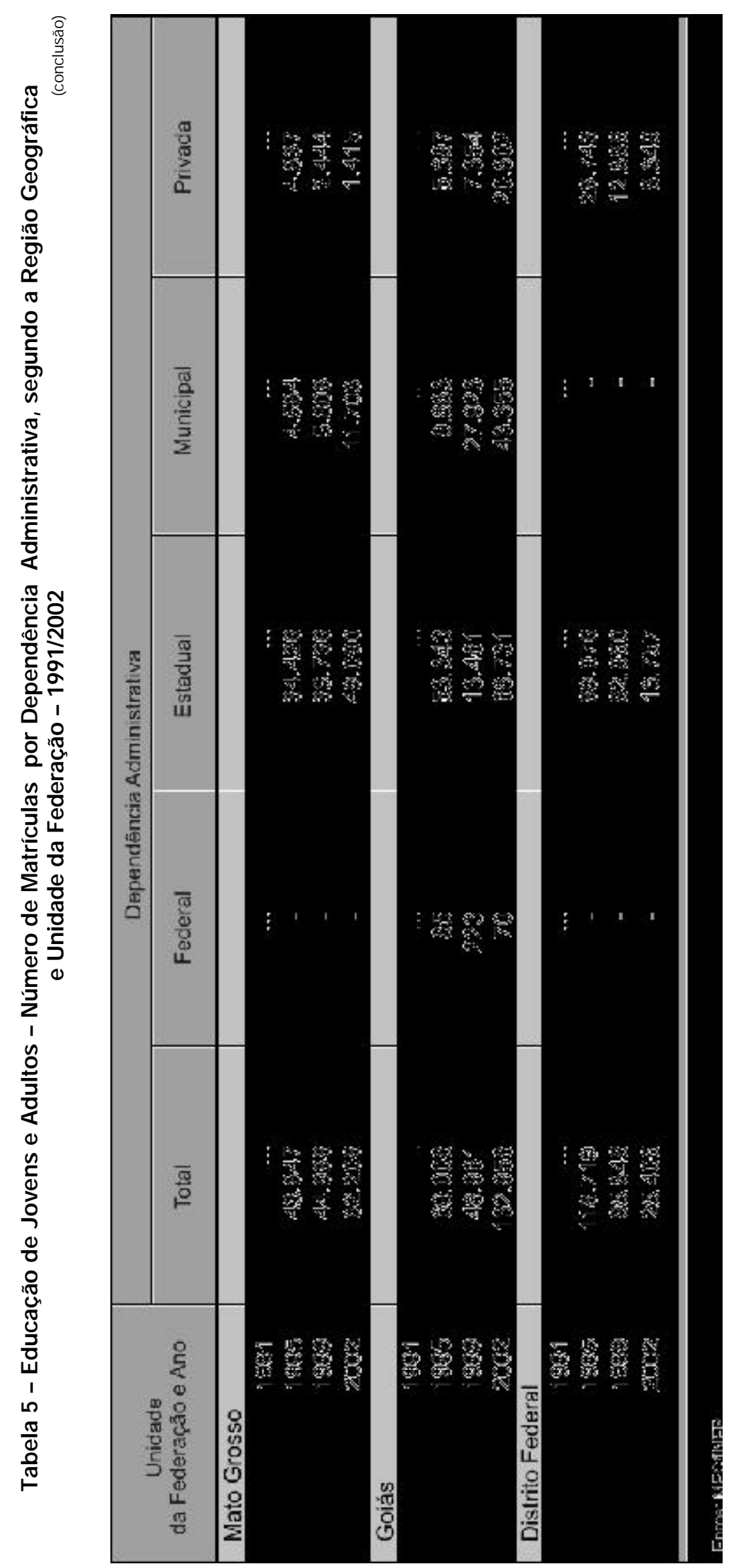

R. bras. Est. pedag., Brasília, v. 81, n. 199, p. 525-567, set./dez. 2000. 


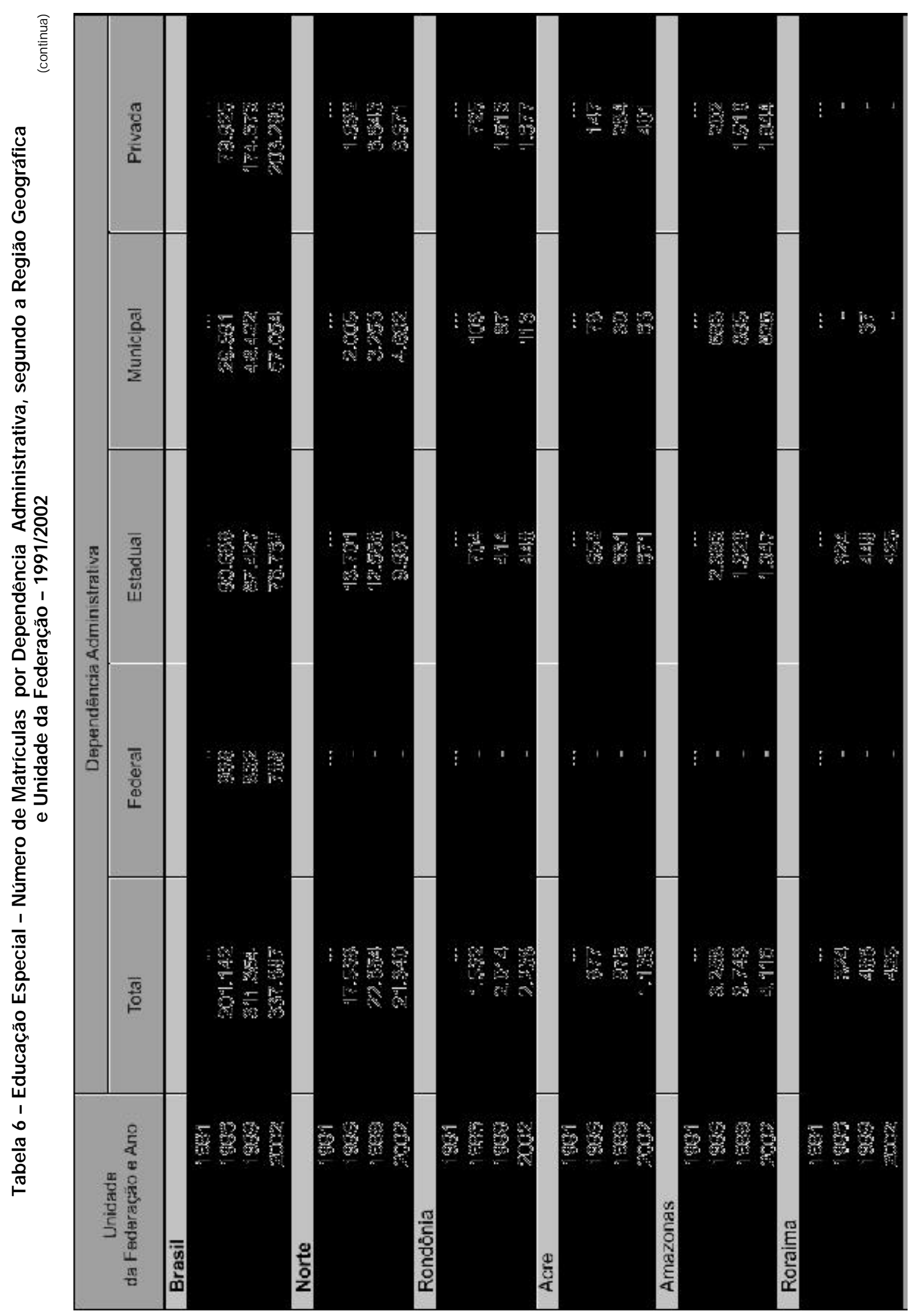




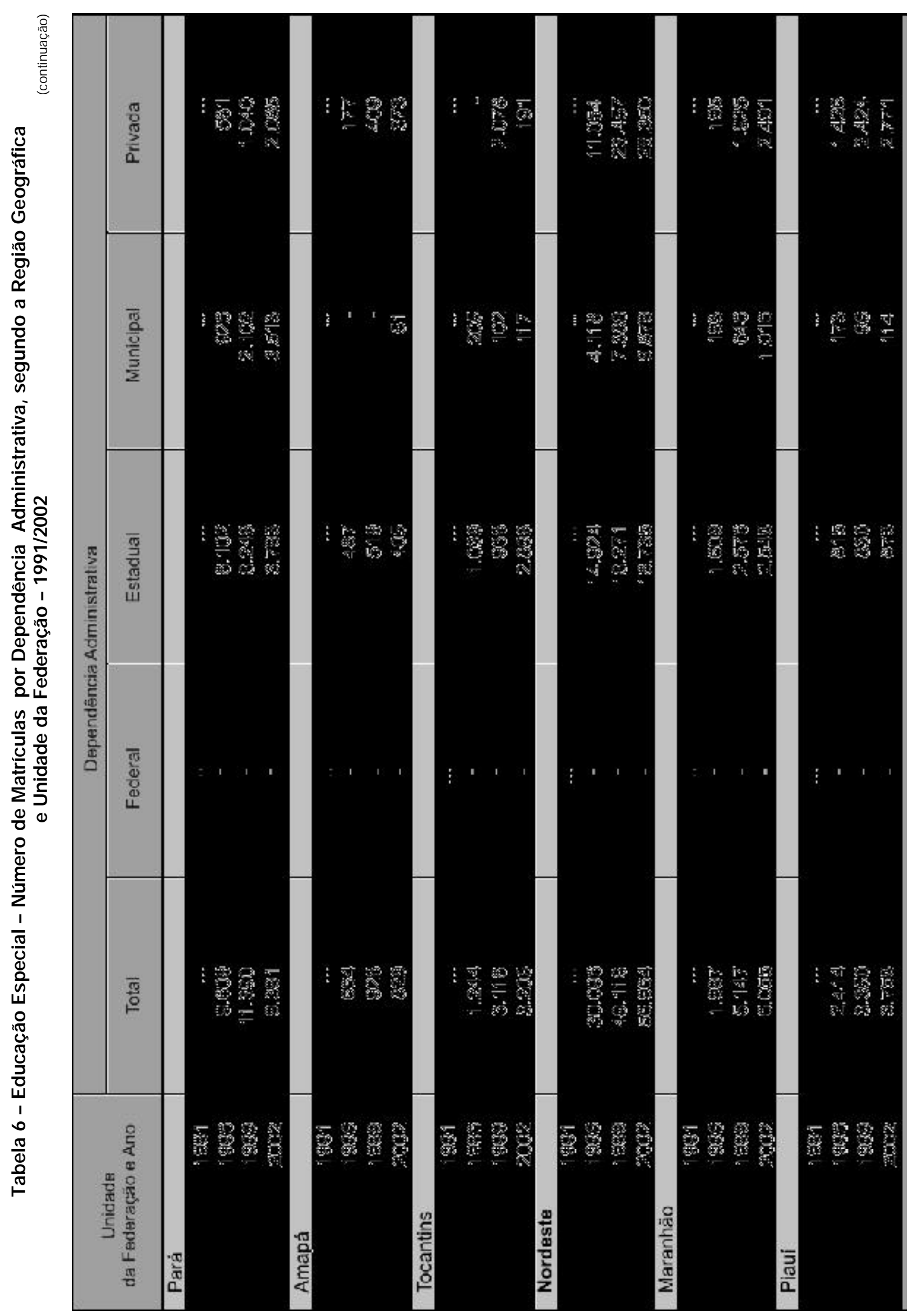




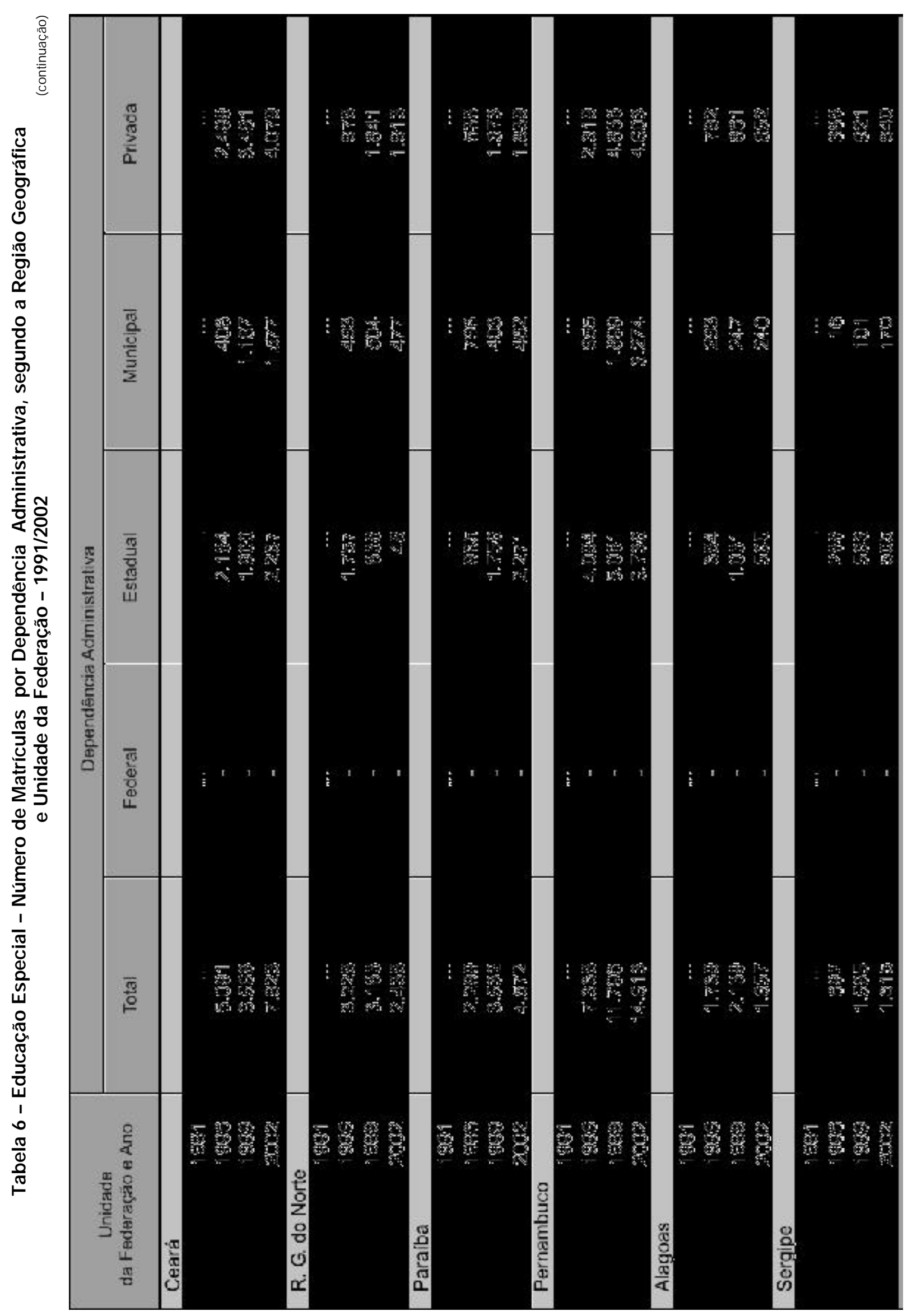




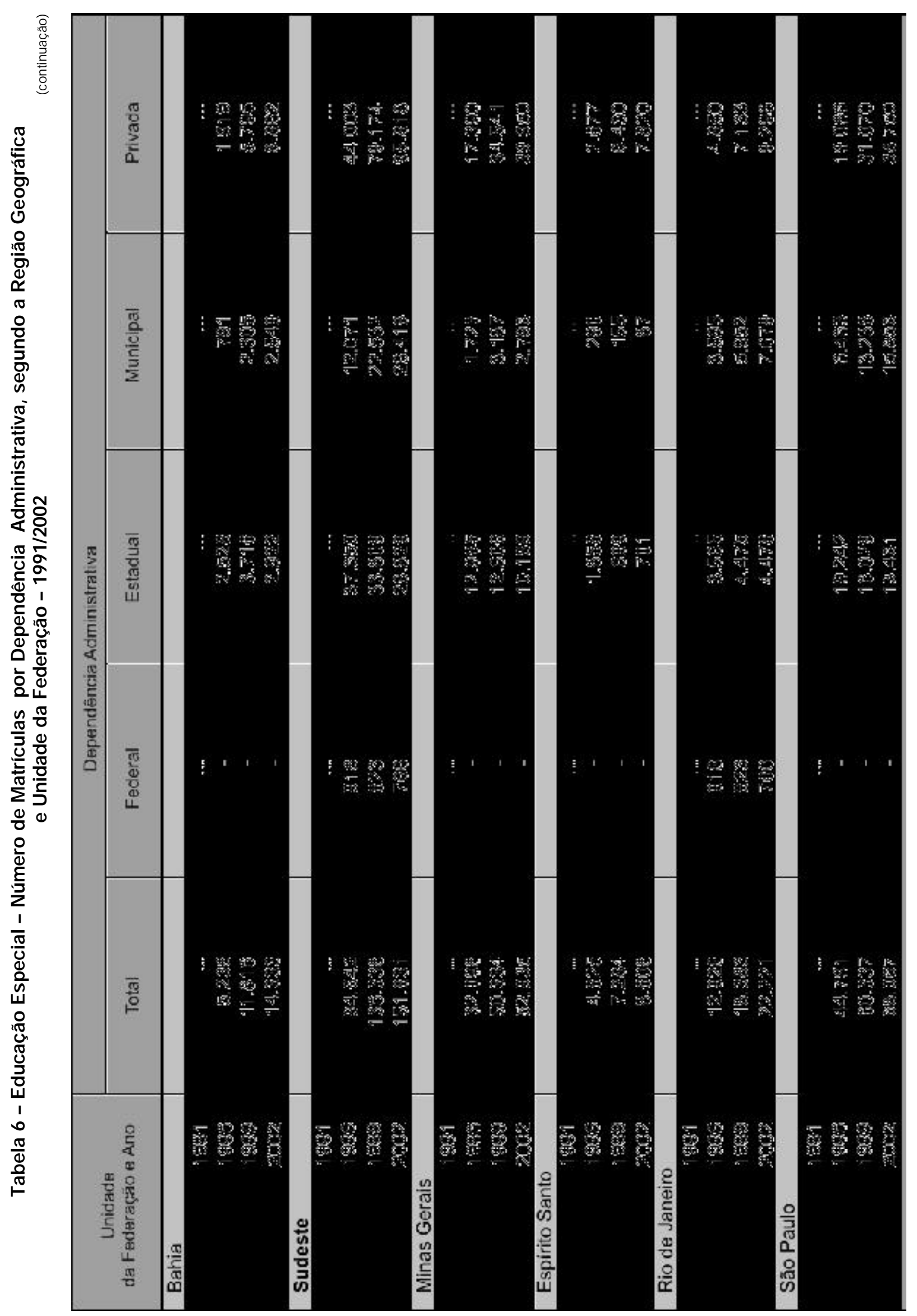




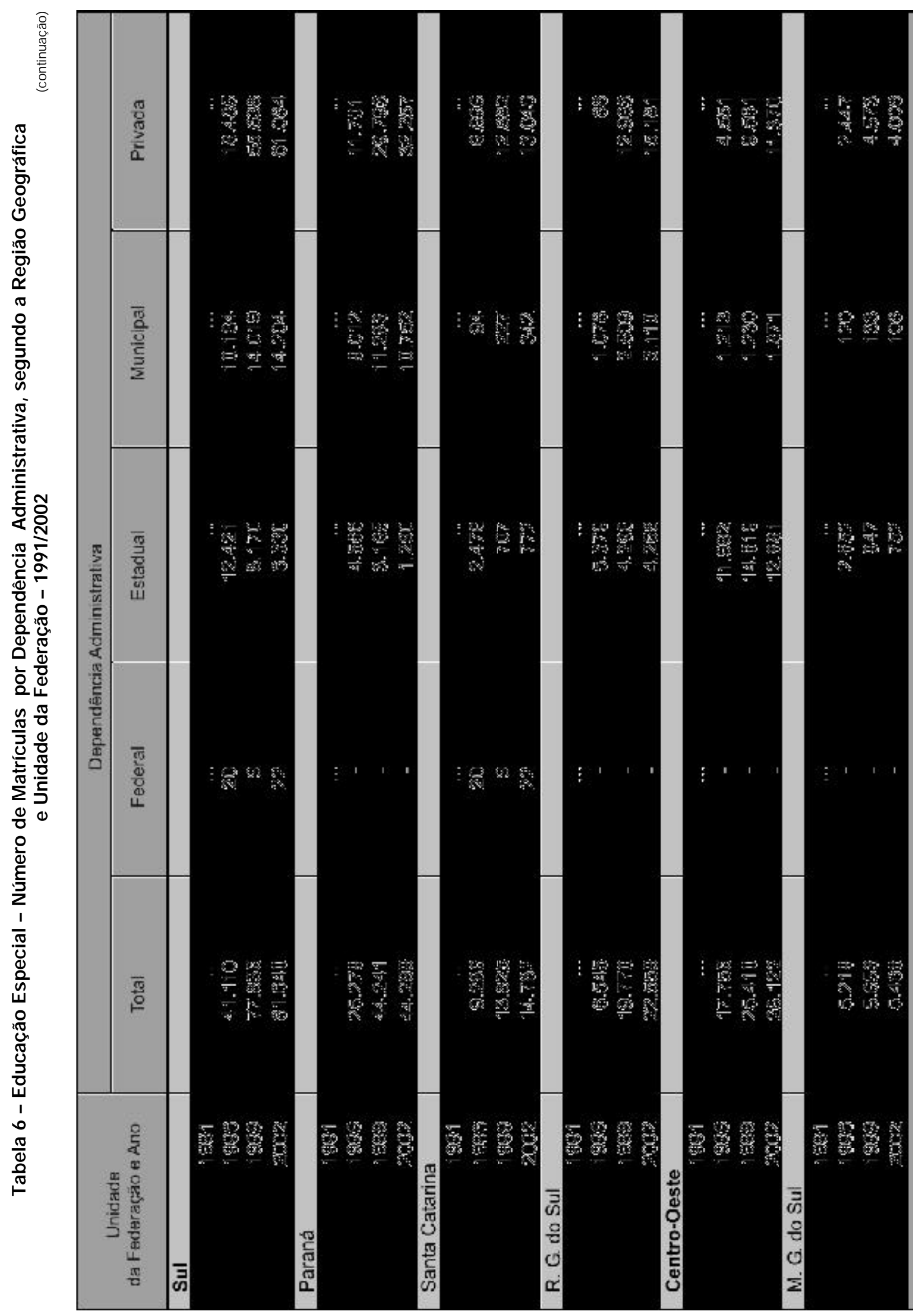




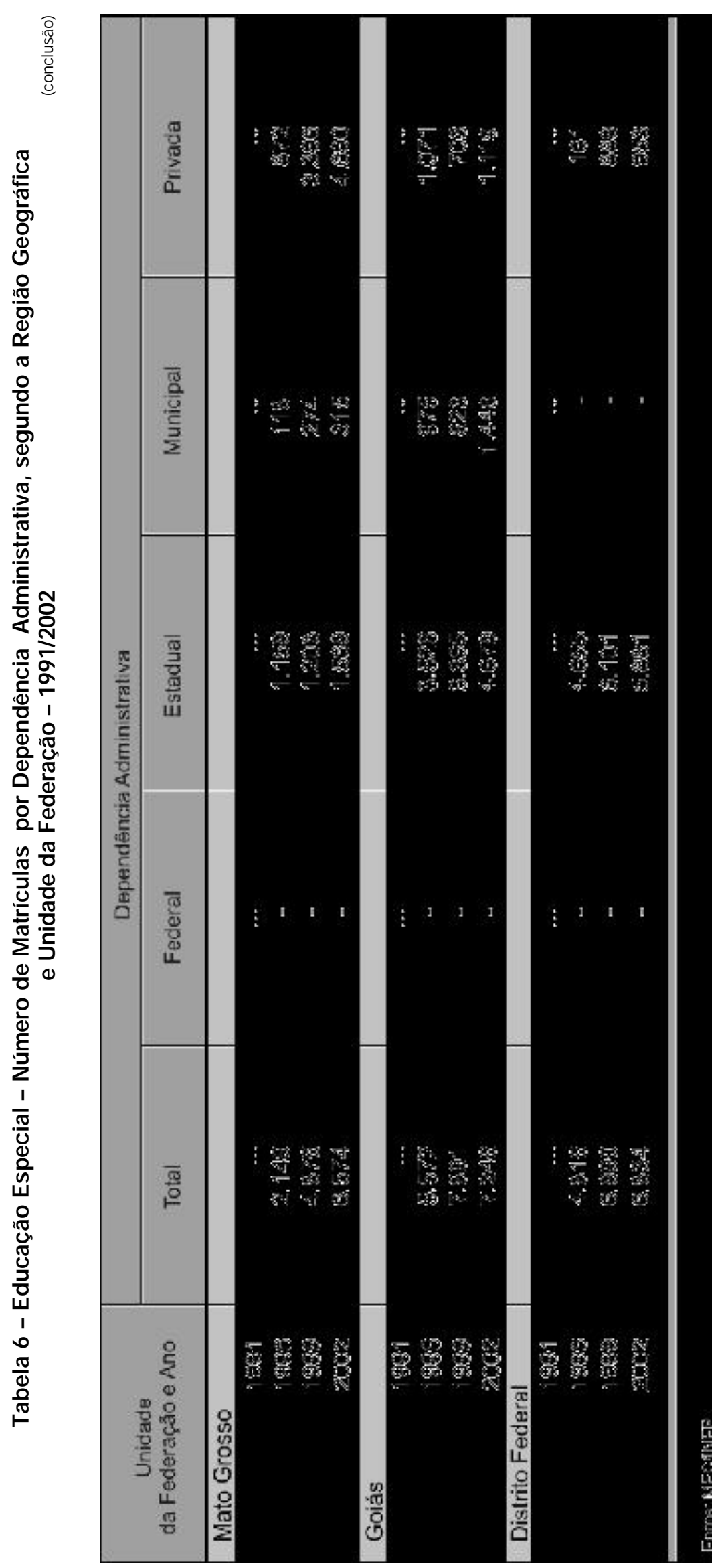

R. bras. Est. pedag., Brasília, v. 81, n. 199, p. 525-567, set./dez. 2000. 


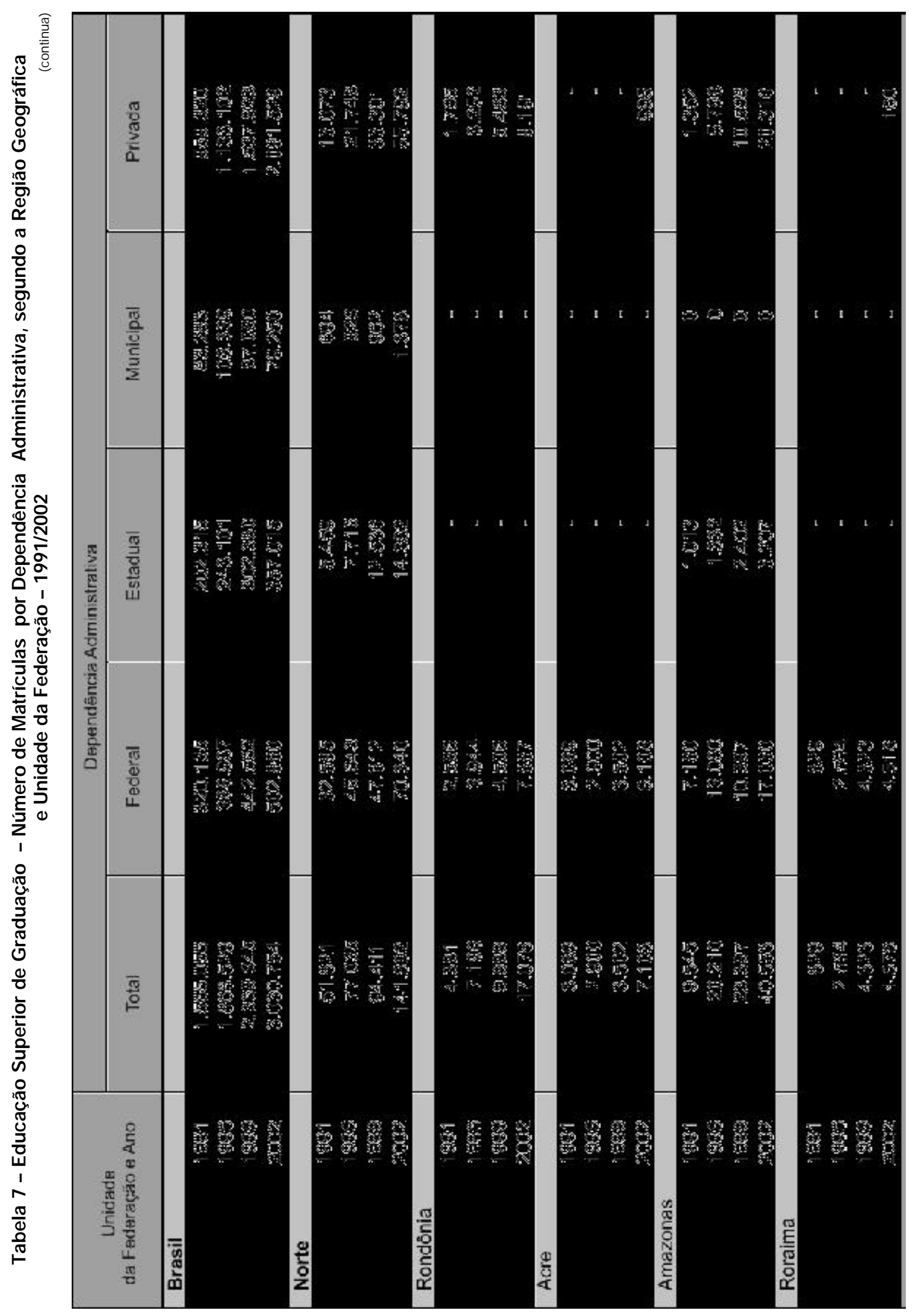




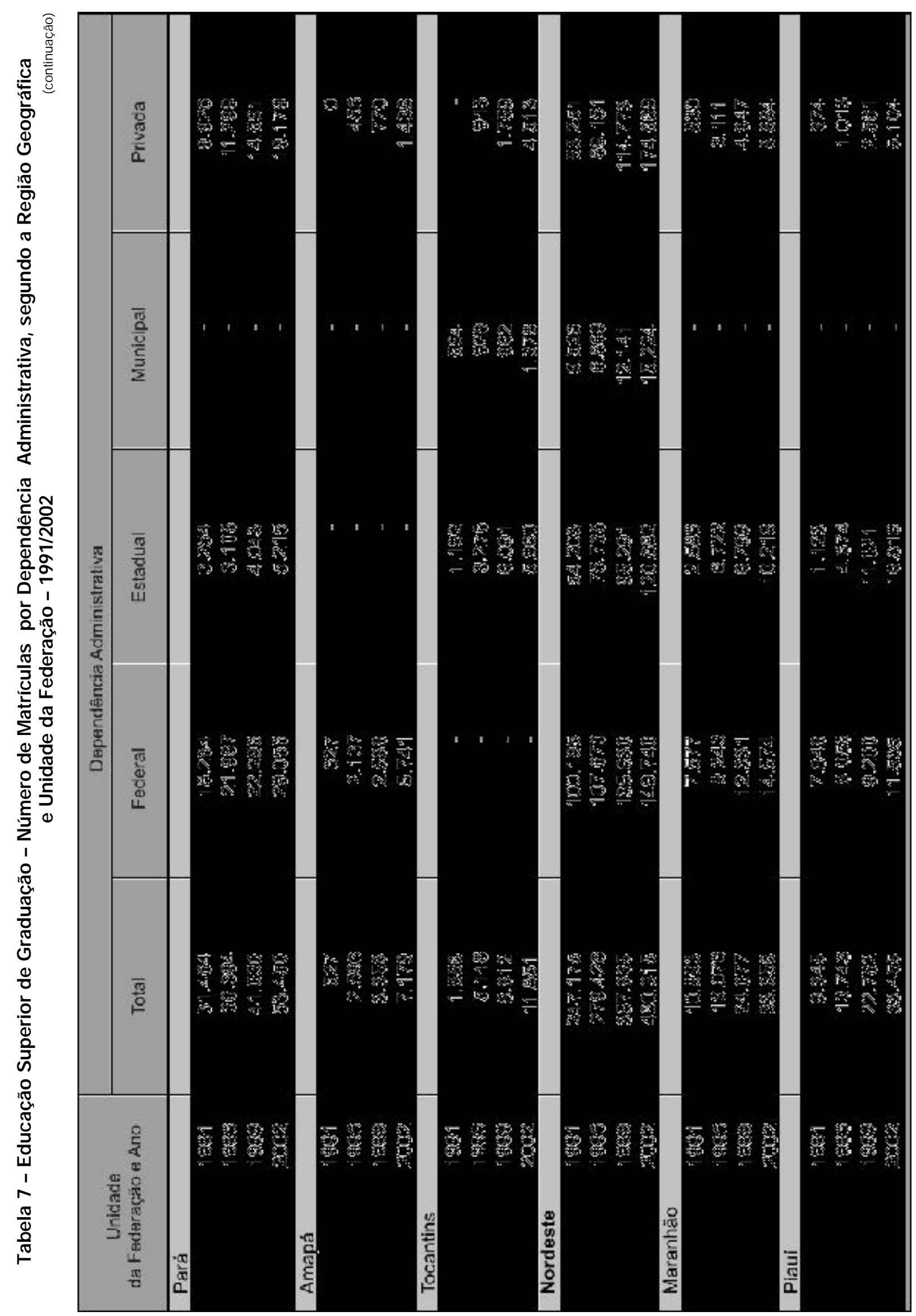




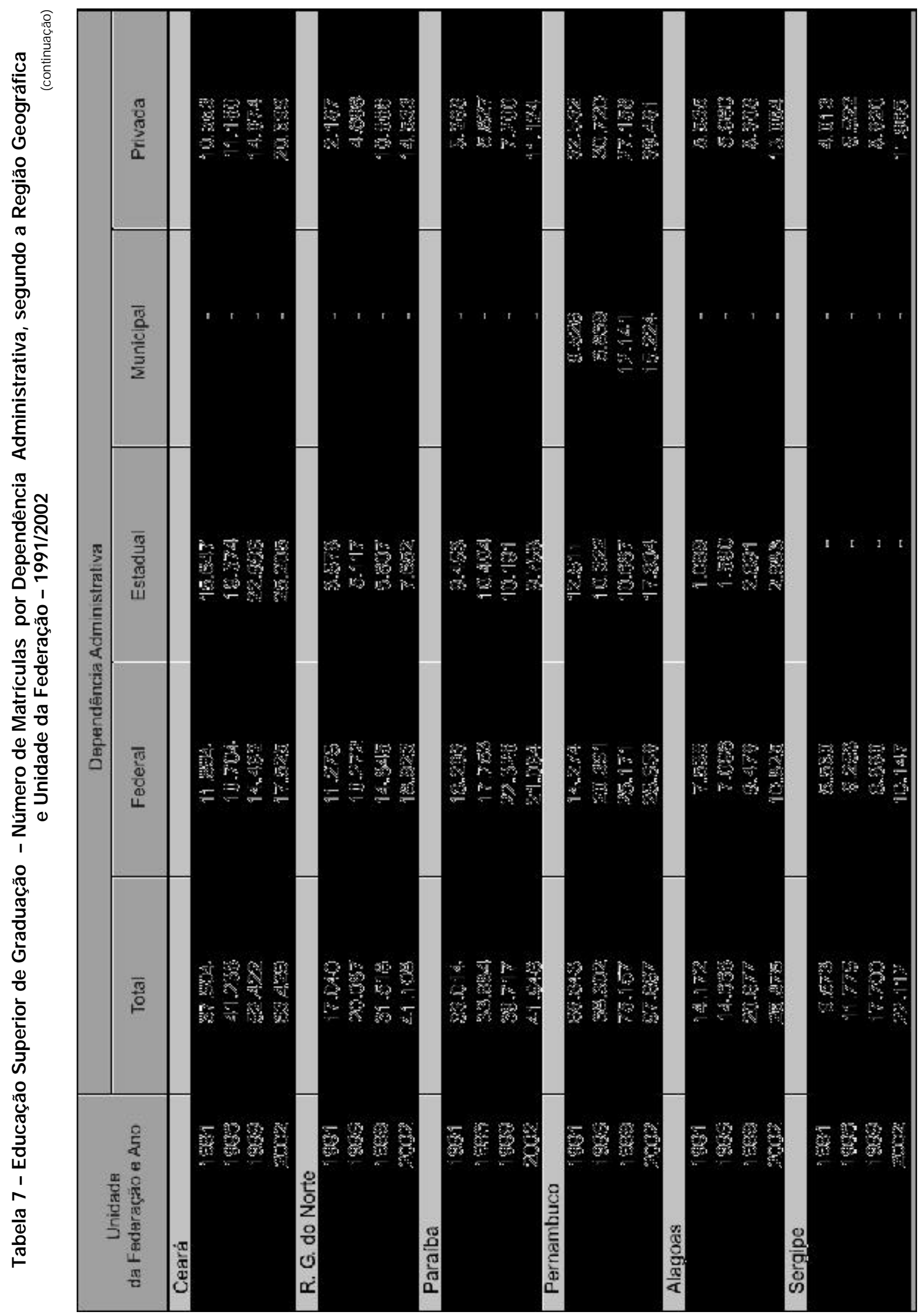




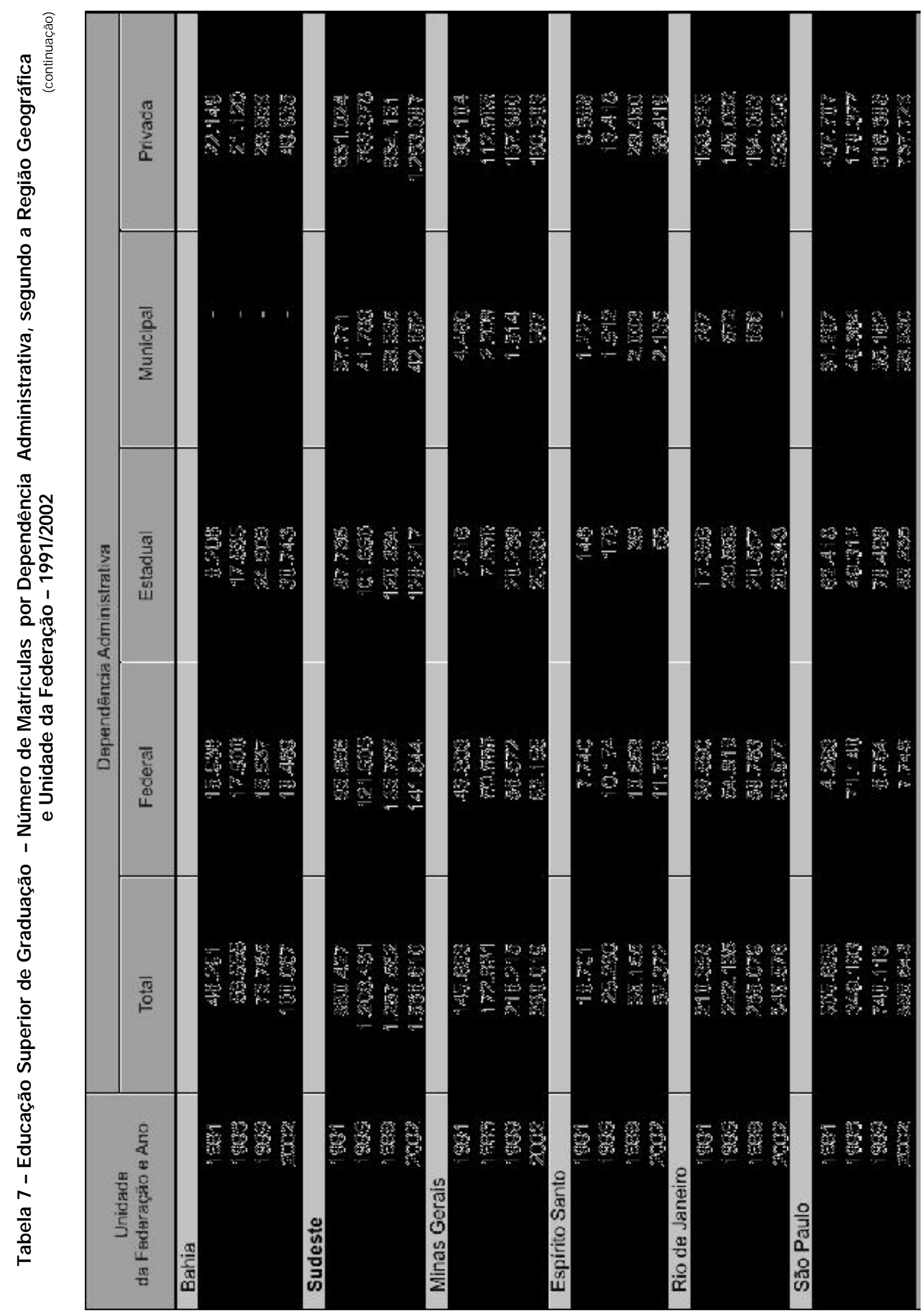




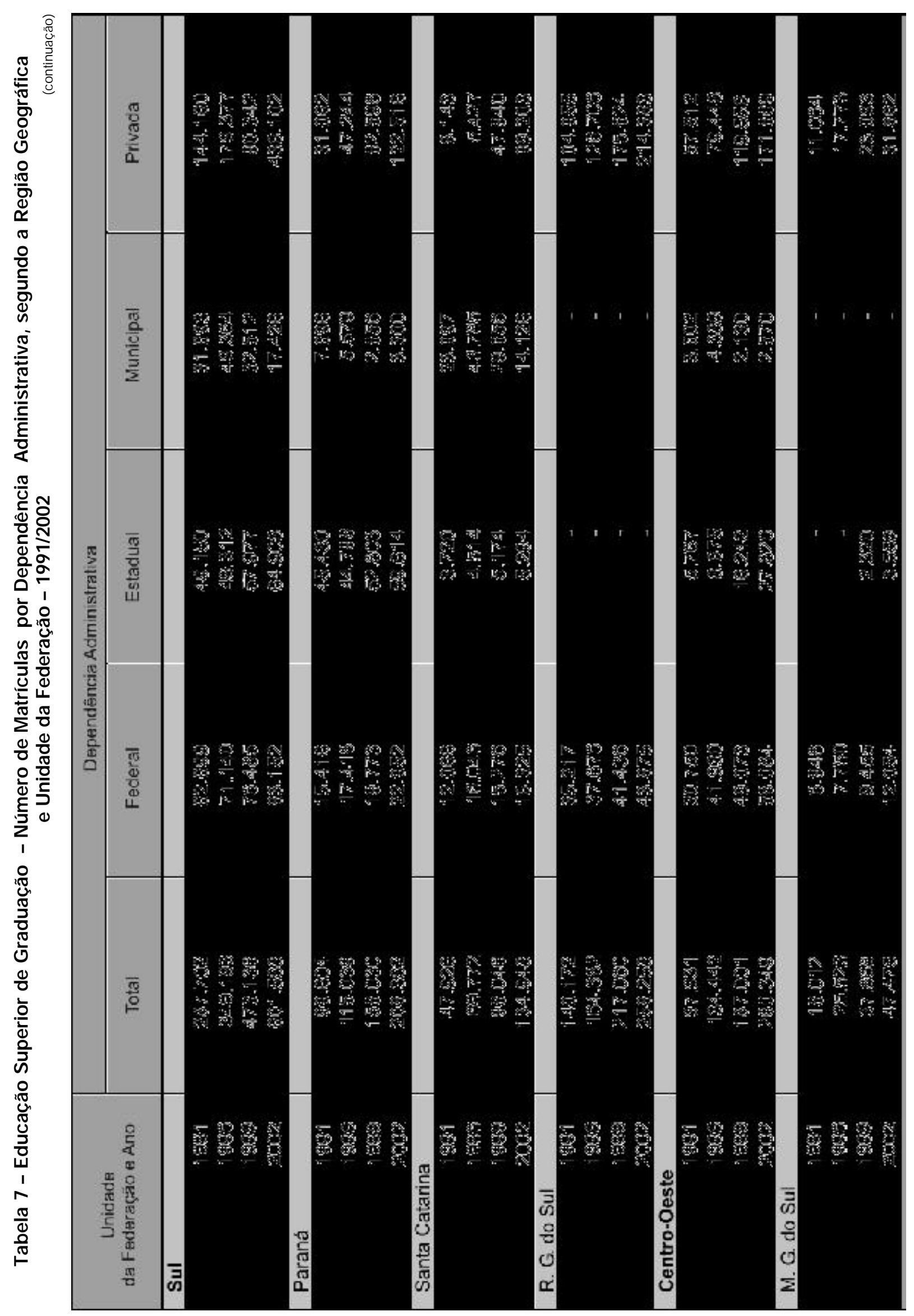




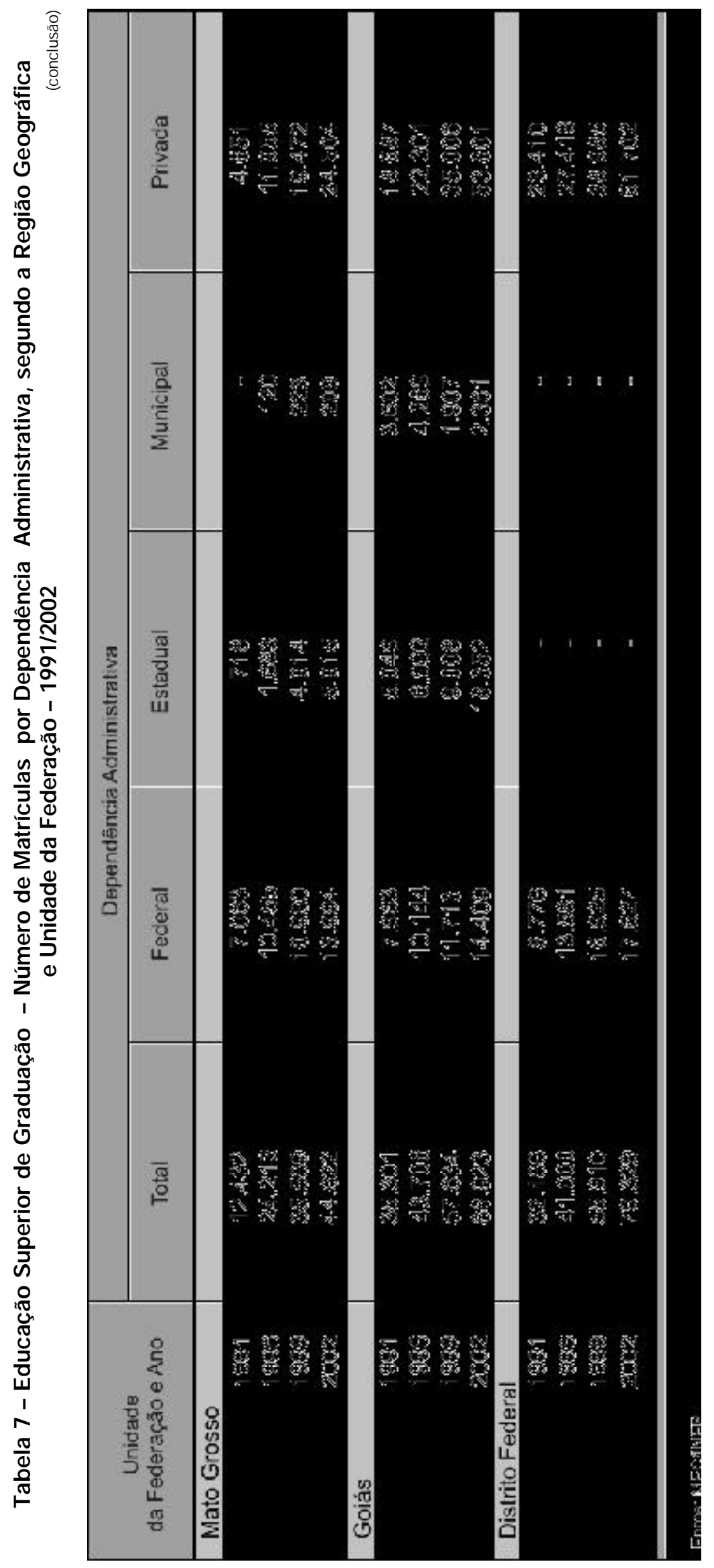

R. bras. Est. pedag., Brasília, v. 81, n. 199, p. 525-567, set./dez. 2000. 


\section{ESTATISTICA}

\section{Censo do Professor 1997}

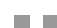

O Censo do Professor foi uma pesquisa realizada pelo Inep em 1997 e que teve como objetivo inicial a criação do Cadastro Nacional de Professores da Educação Básica, o qual permitiria uma comunicação direta entre o MEC e esses professores. Entretanto, o volume de informações levantadas permitiu ao Inep desenvolver análises do perfil desses professores, considerando algumas segmentações de interesse, que resultaram na publicação Censo do professor 1997 - Perfil do magistério da educação básica (www.inep.gov.br).

Os instrumentos de coleta (questionários e instruções de preenchimento) foram enviados diretamente aos diretores das escolas, que os distribuíram aos professores, prestando os esclarecimentos necessários ao seu preenchimento. 0 retorno dos questionários preenchidos ficou a cargo dos próprios diretores, que os devolveram via correio, em envelope com porte pago.

Por tratar-se de uma pesquisa com resposta voluntária, o percentual de respostas ficou em torno de $90 \%$, em comparação com os resultados do Censo Escolar de 1997.

Vale ressaltar, contudo, alguns problemas observados nos dados devido a faIhas no planejamento e na execução da pesquisa. Em relação ao planejamento, 0 fato de os questionários não terem sido impressos já com o código da escola permitiu a ocorrência de casos de inconsistência com o cadastro de escolas do Censo Escolar. Quanto à execução da pesquisa, a ausência de um procedimento mais apurado de crítica visual, aliada a um sistema de entrada de dados permissivo, sem conferência de digitação (dupla digitação, por exemplo), prejudicou a qualidade final da base de dados. Outro problema importante se deu na identificação do professor, devido ao fato de o CPF e o RG não serem campos obrigatórios, além dos erros no seu preenchimento, utilizados como possíveis indexadores dos professores, visto que estes preencheriam o questionário em todas as escolas em que atuassem.

Contudo, esses problemas foram minimizados após realizar-se um grande trabalho de "limpeza" e consistência das informações com o Censo Escolar de 1997, com correção na base de dados, fixando critérios para os salários, segundo a dependência e o grau de formação do docente, critérios para idade e, também, para os anos de regência e de magistério, entre outras medidas.

Diante do objetivo inicial da pesquisa, o questionário não foi exaustivo quanto a algumas questões importantes, como, por exemplo, a carga horária do professor, ponto fundamental no cálculo do salário médio, que não foi levantada. Contudo, a importância dessa base de dados é inquestionável, já que se trata do único levantamento dessa ordem no Brasil, com significativa abrangência (mais de 90\%, como já foi mencionado), e que registra, entre outras informações, o salário e os anos de regência e atuação no magistério da Educação Básica.

Nesta publicação, são apresentadas estatísticas básicas sobre o salário dos professores, obtidas a partir desse levantamento. Os dados trazem informações sobre salários por unidade da Federação, segundo a esfera administrativa e o grau de formação dos docentes.

Neste ano de 2003, o Inep pretende realizar um novo Censo do Professor, em cuja organização almeja contar com a participação ativa de entidades representativas do segmento docente, com o objetivo de evitar os problemas aqui comentados. 


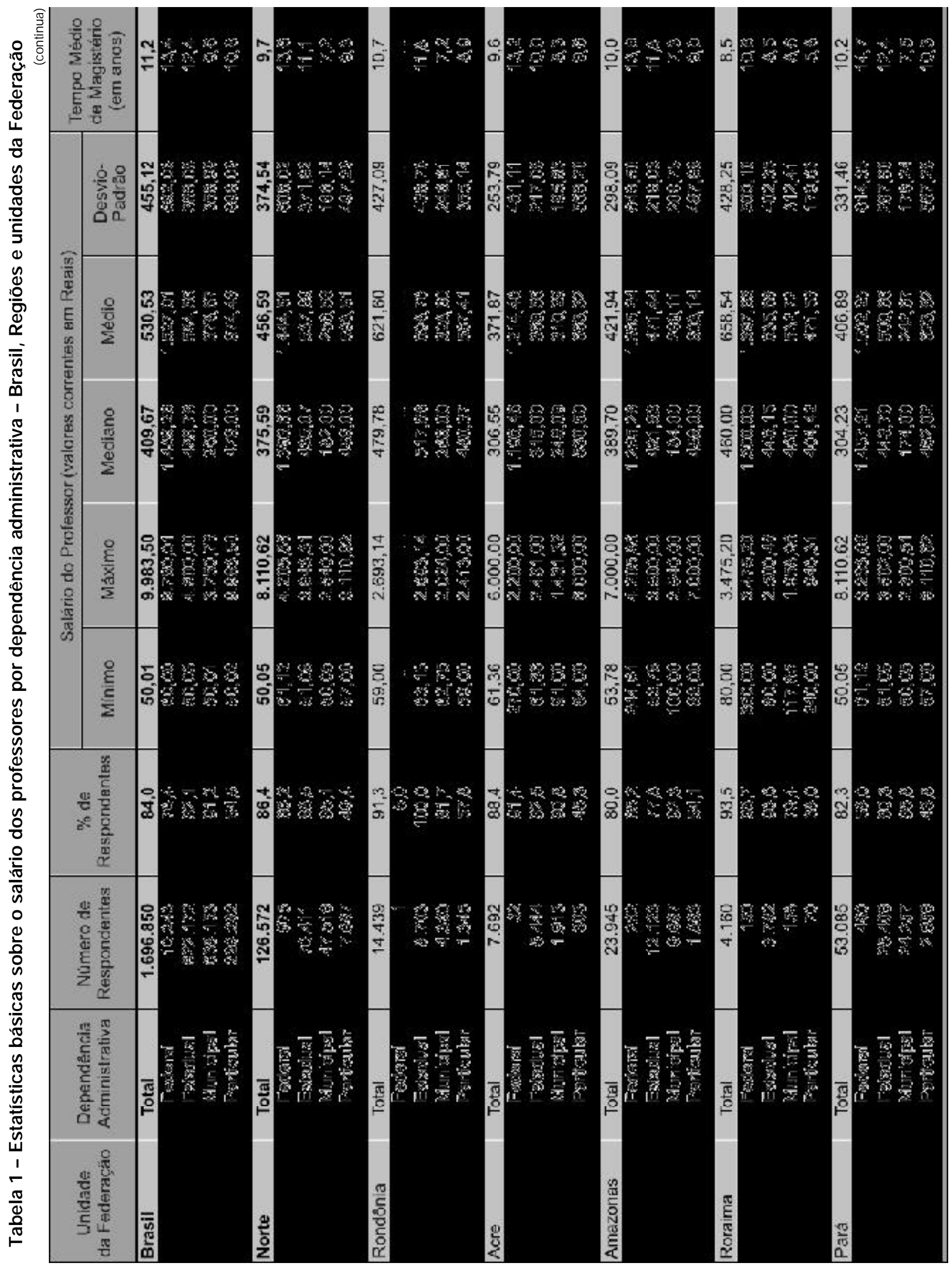




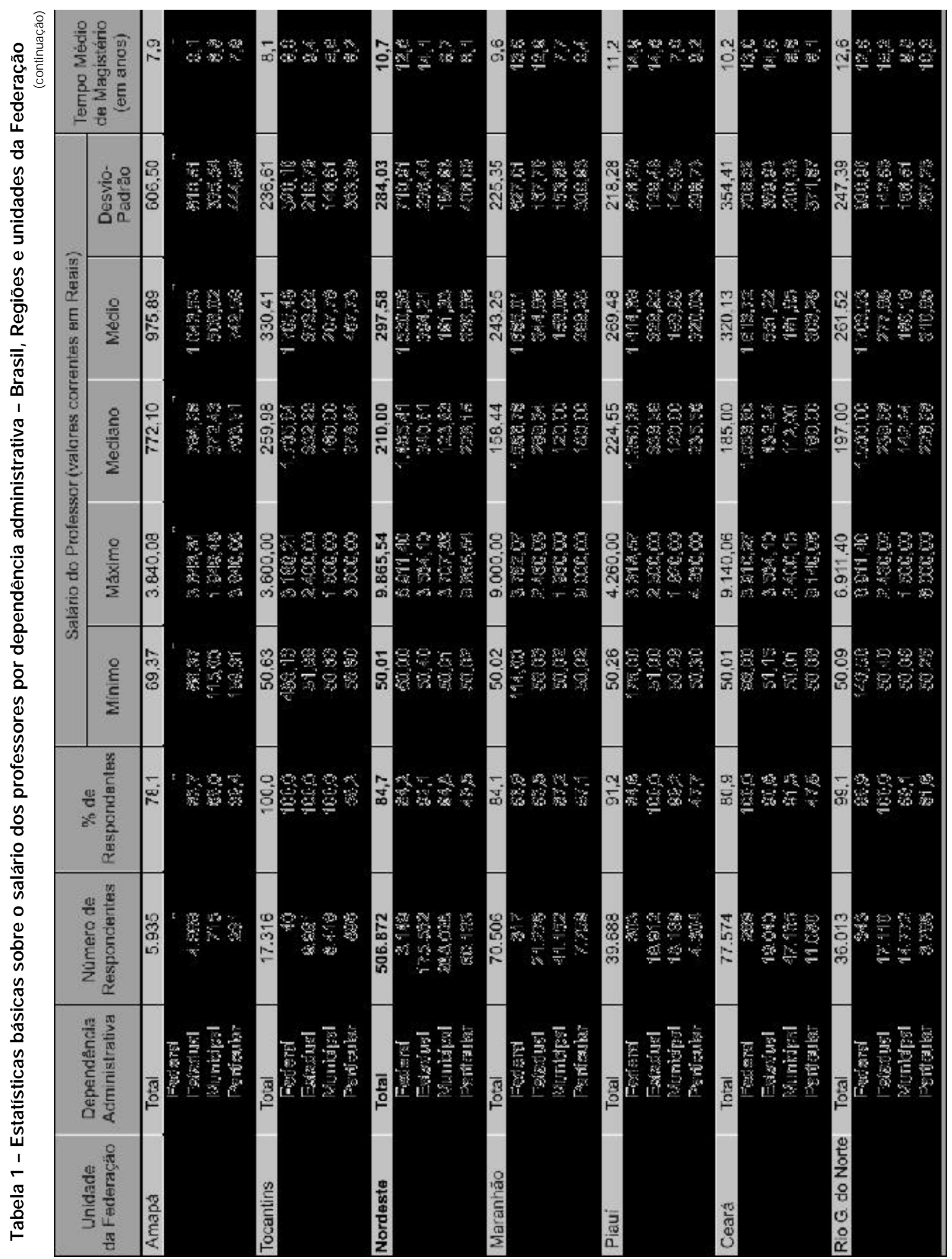




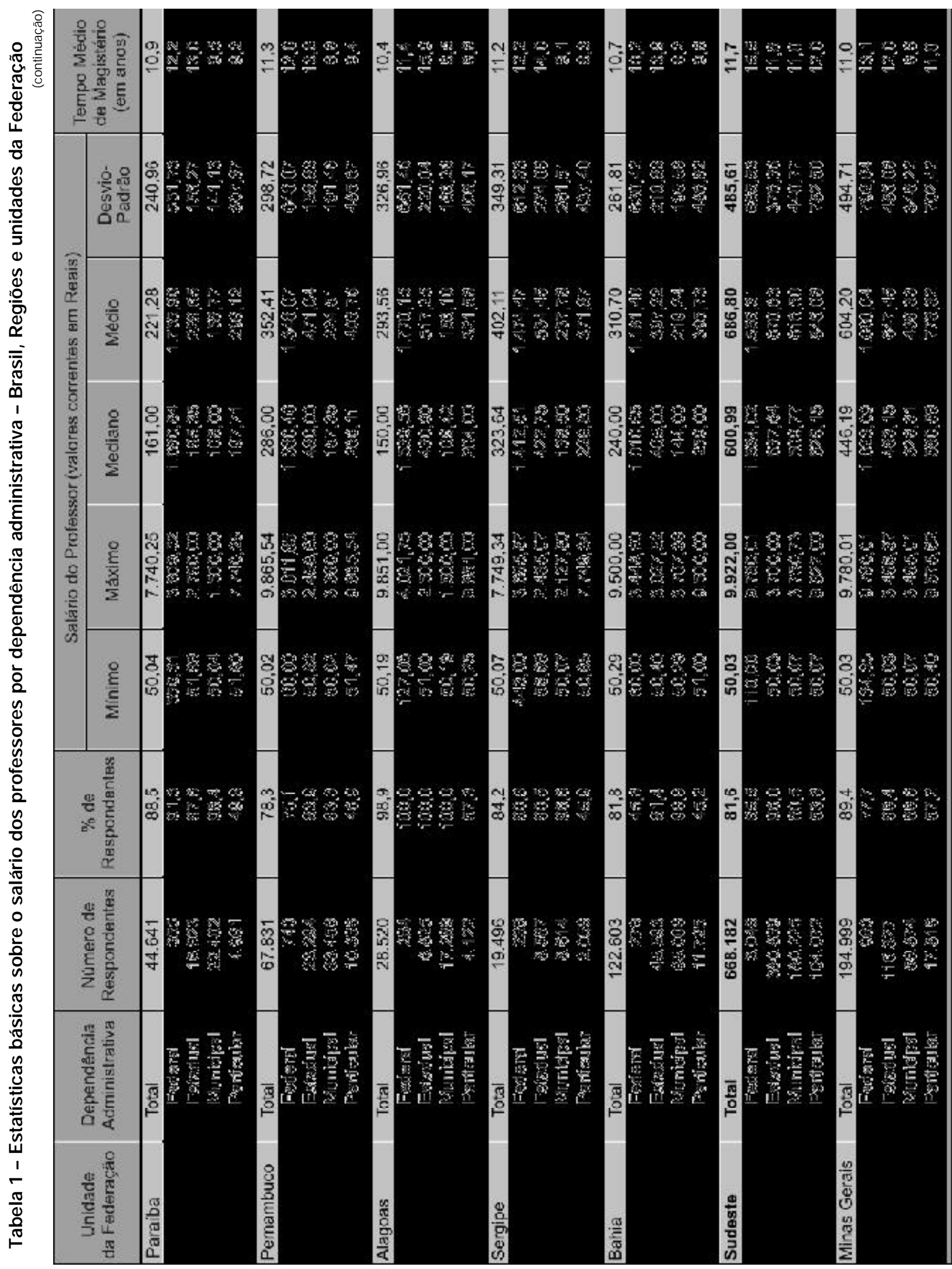




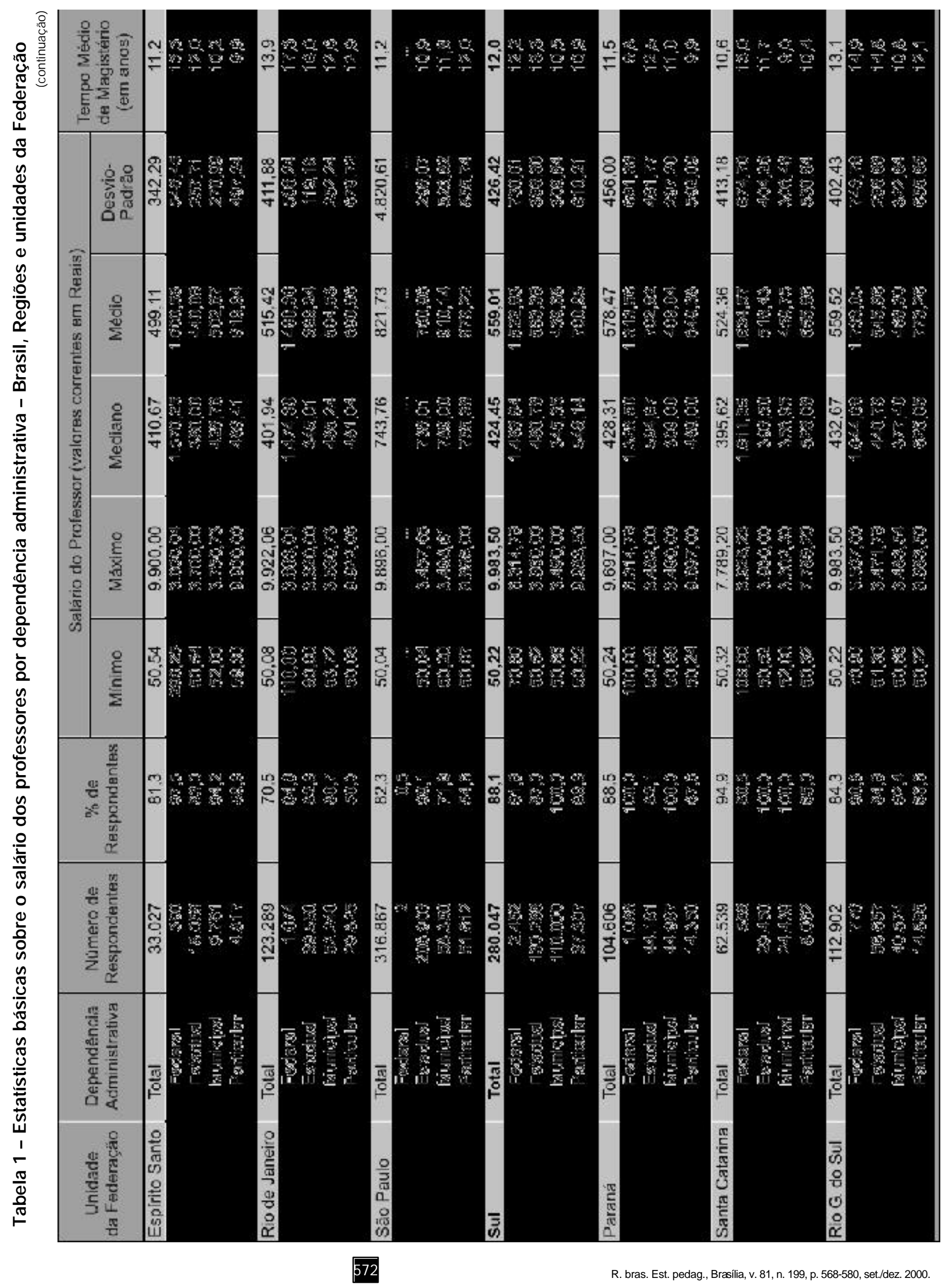




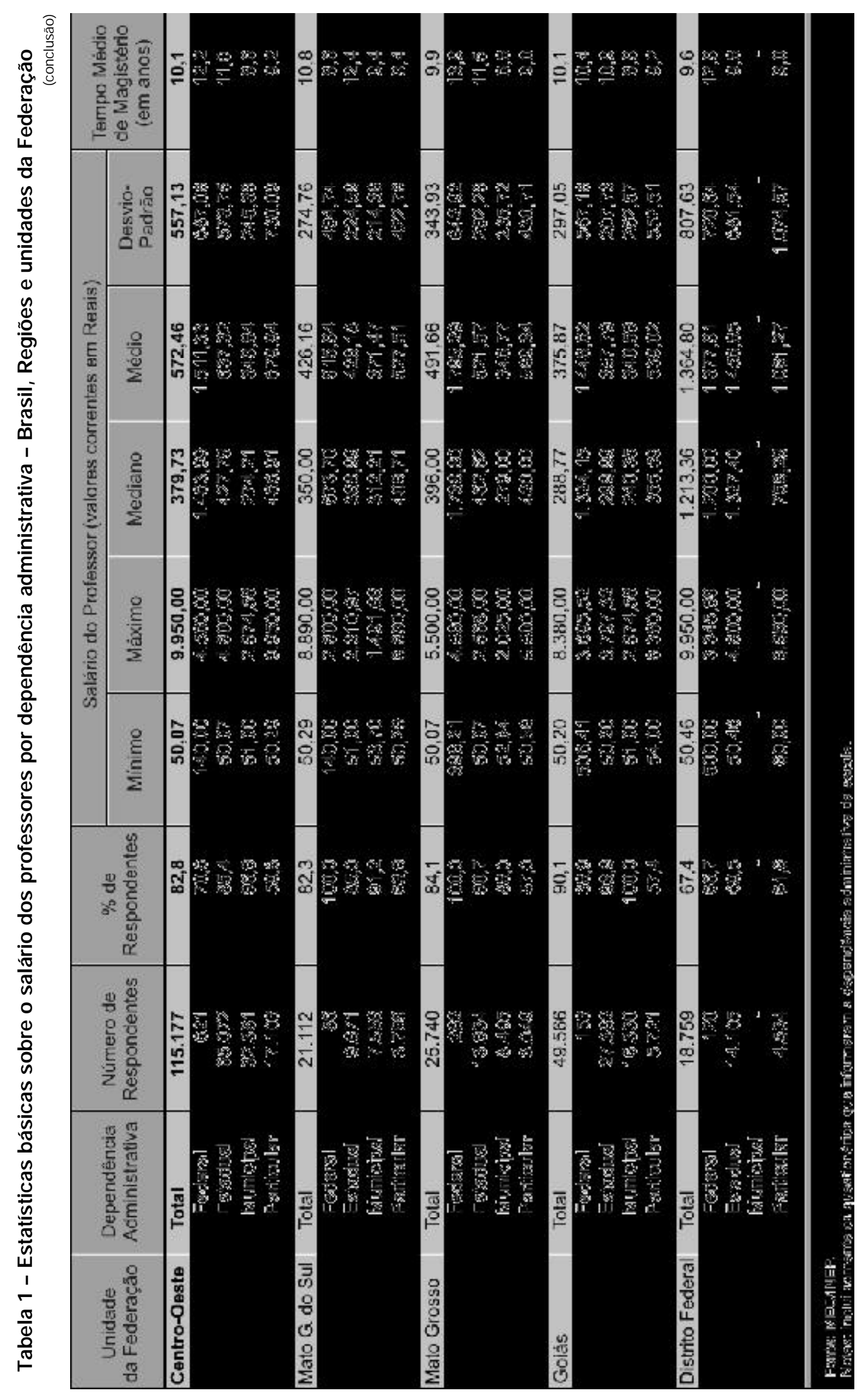




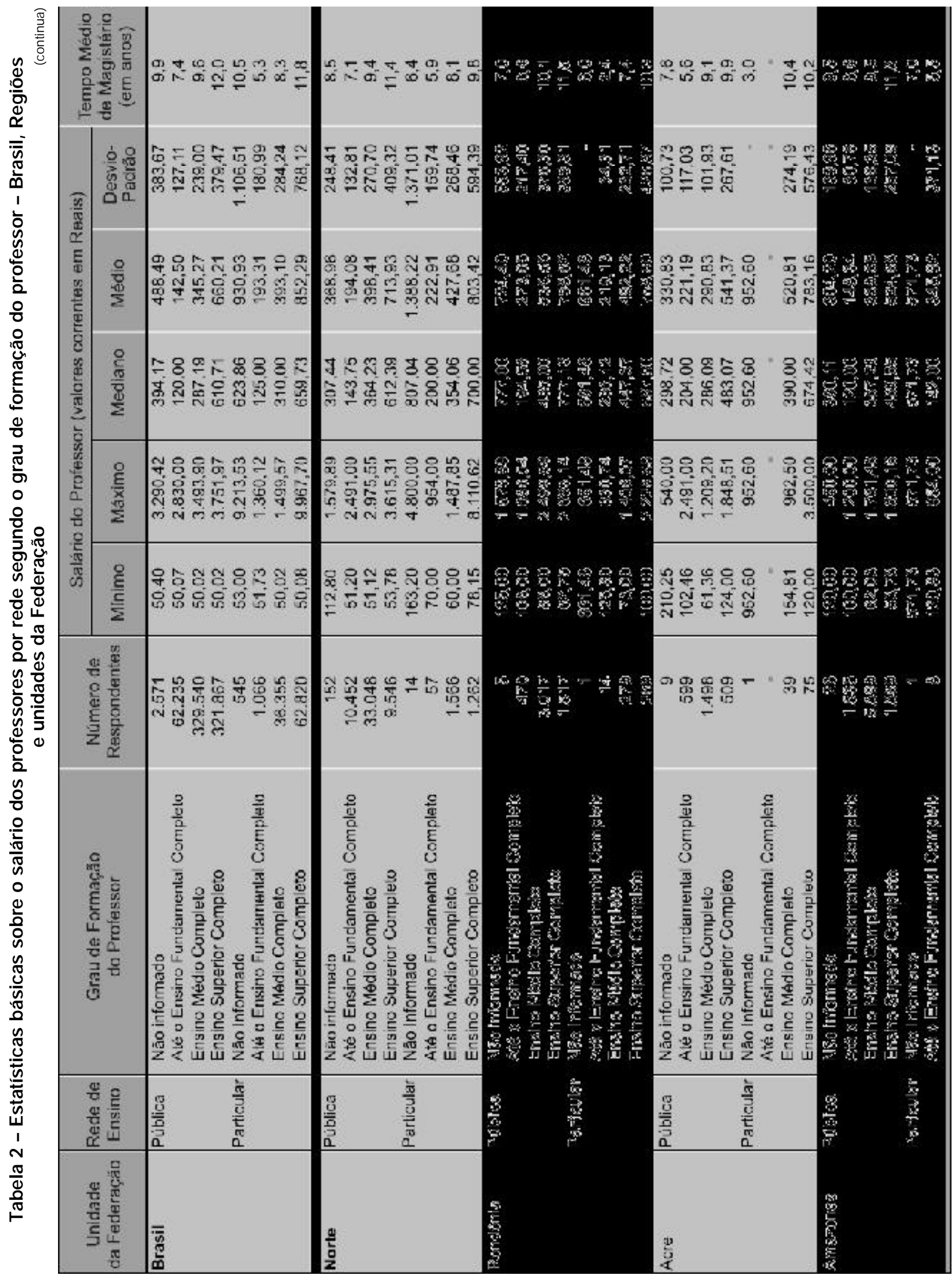




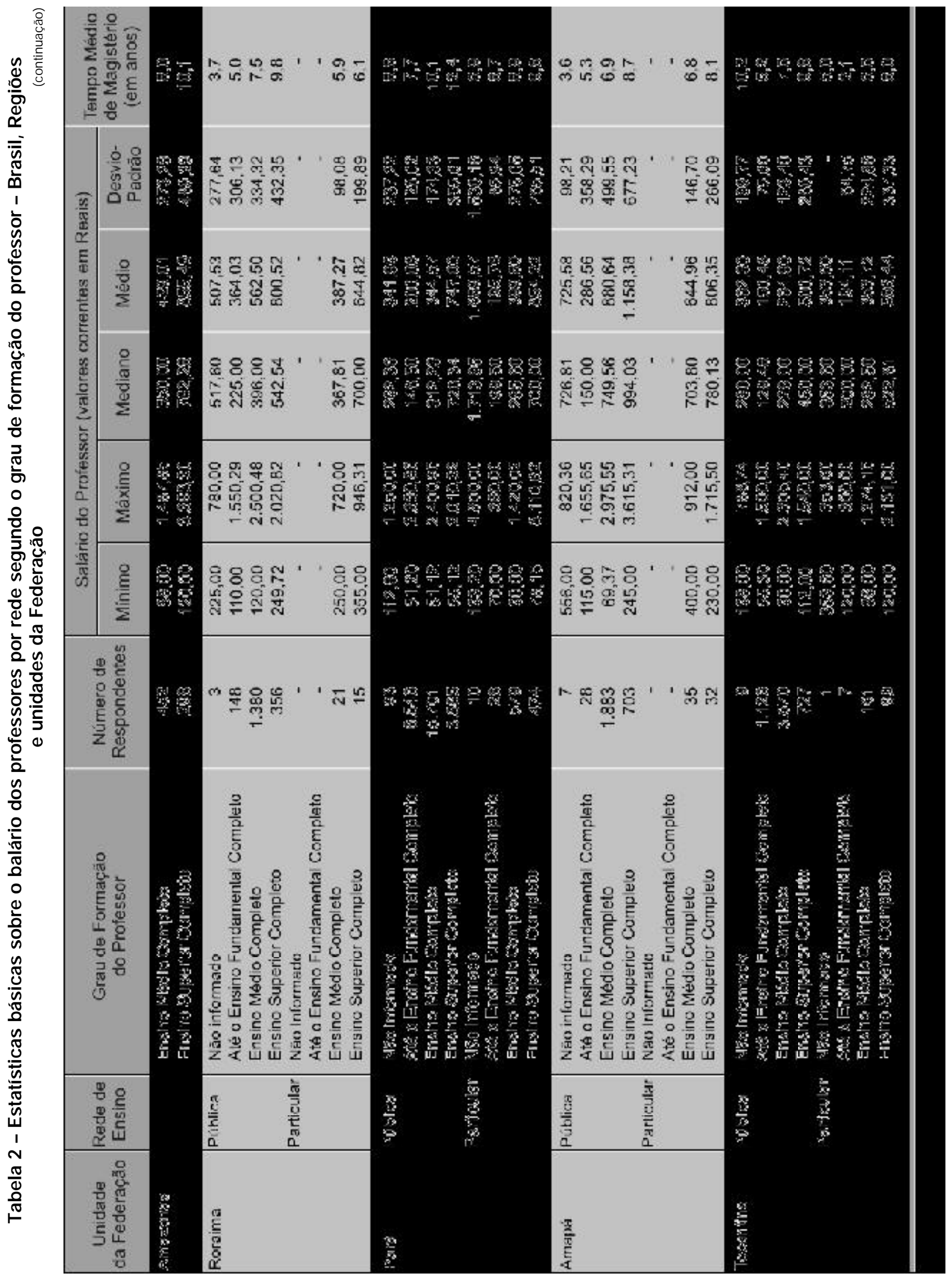




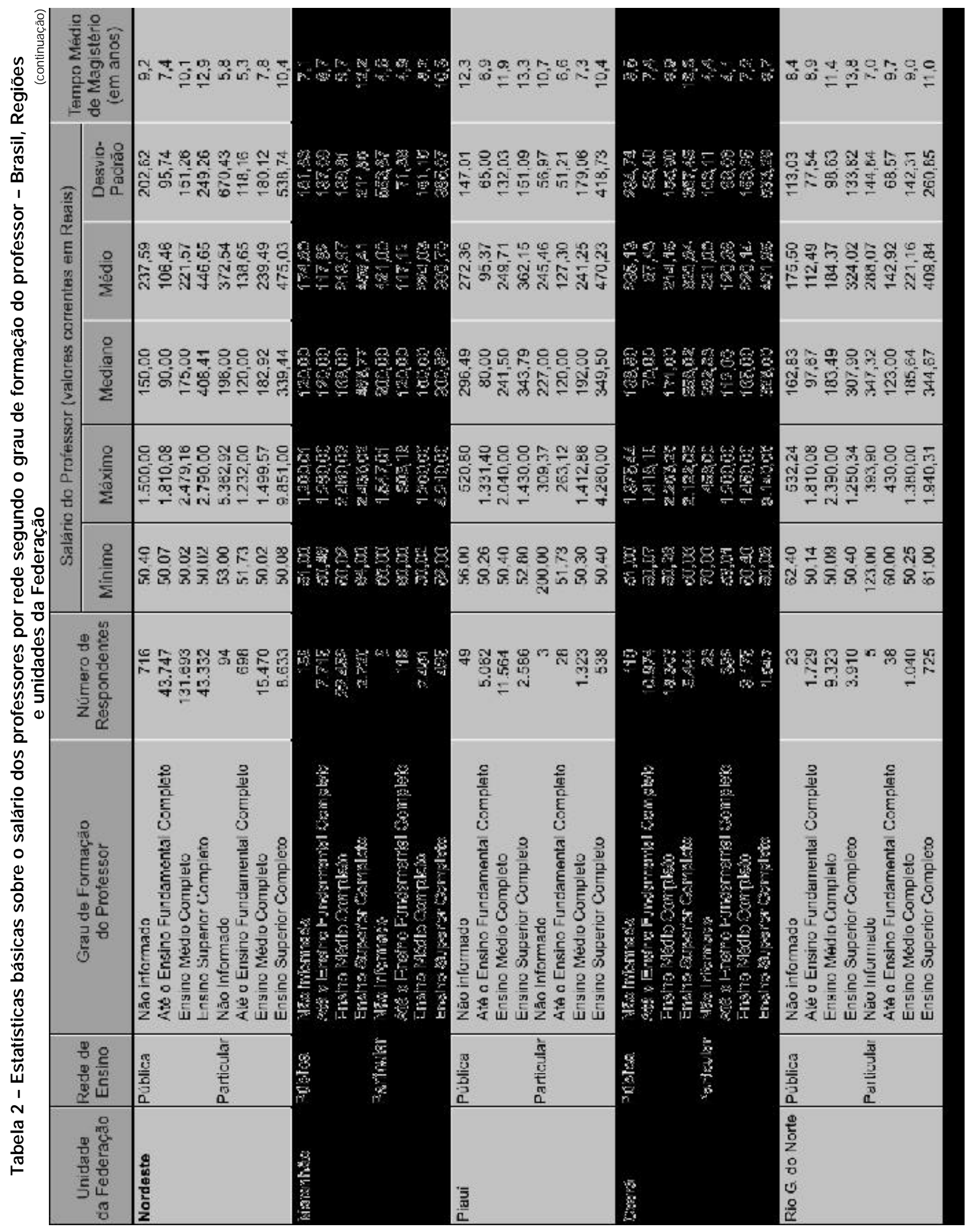




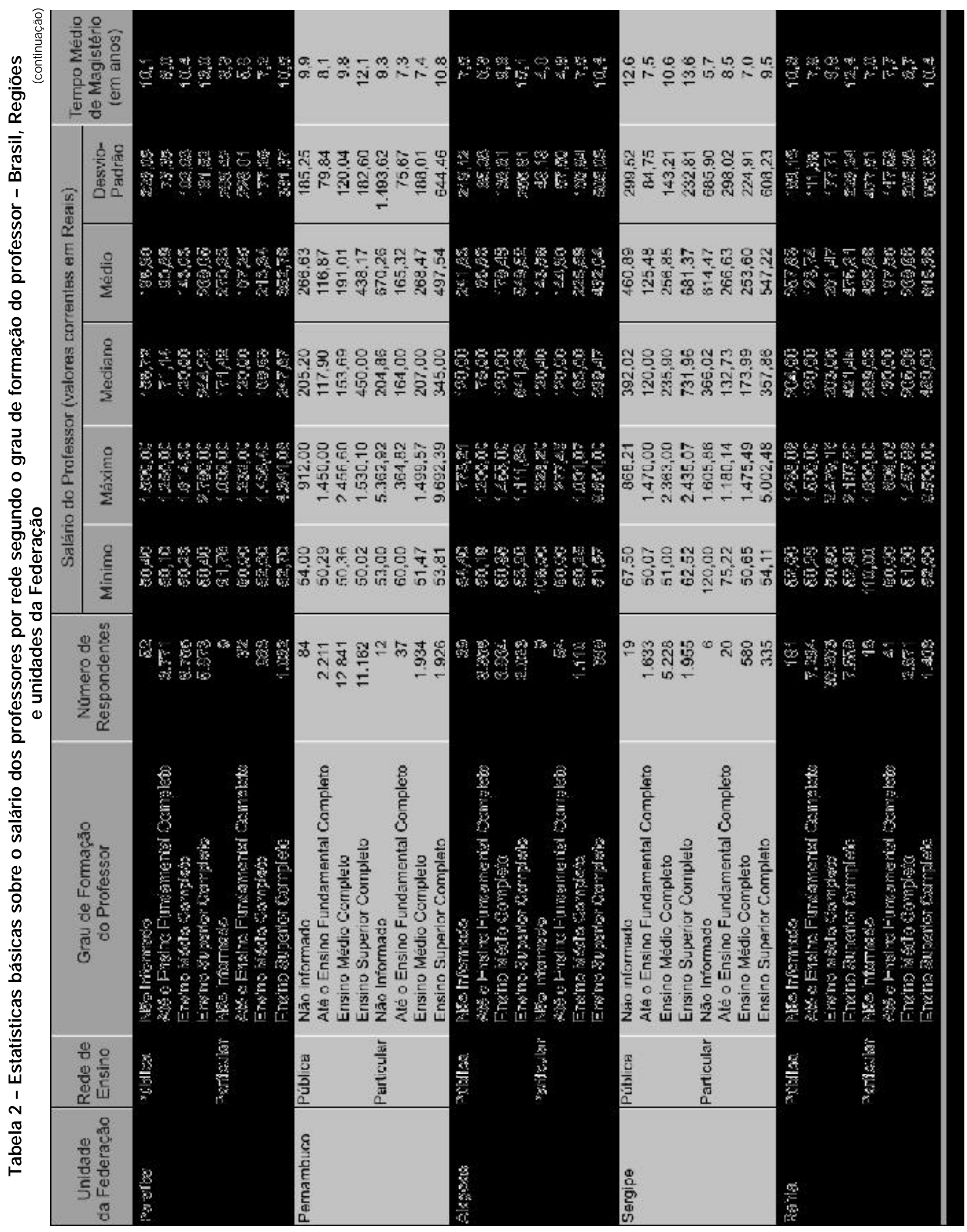




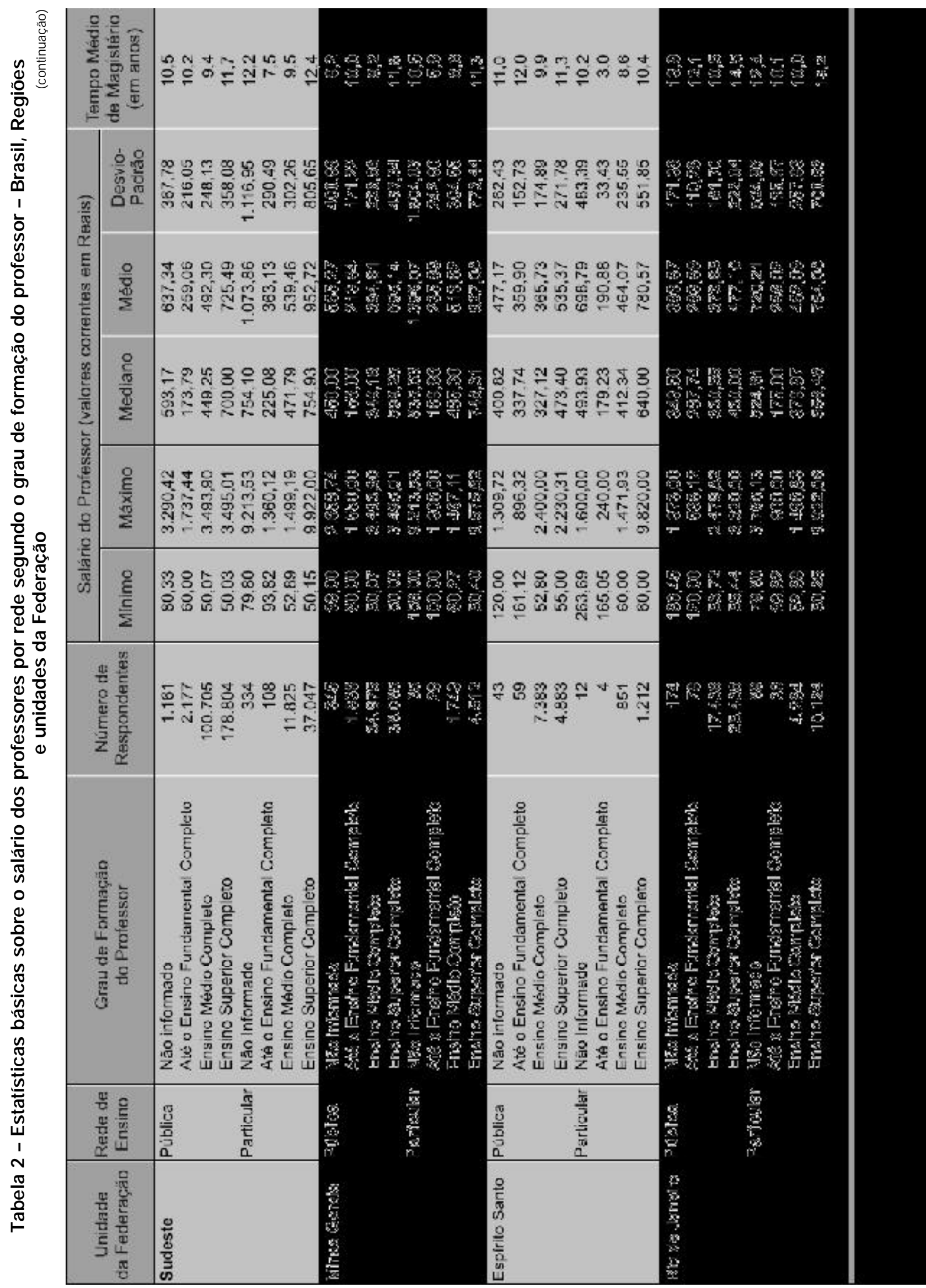




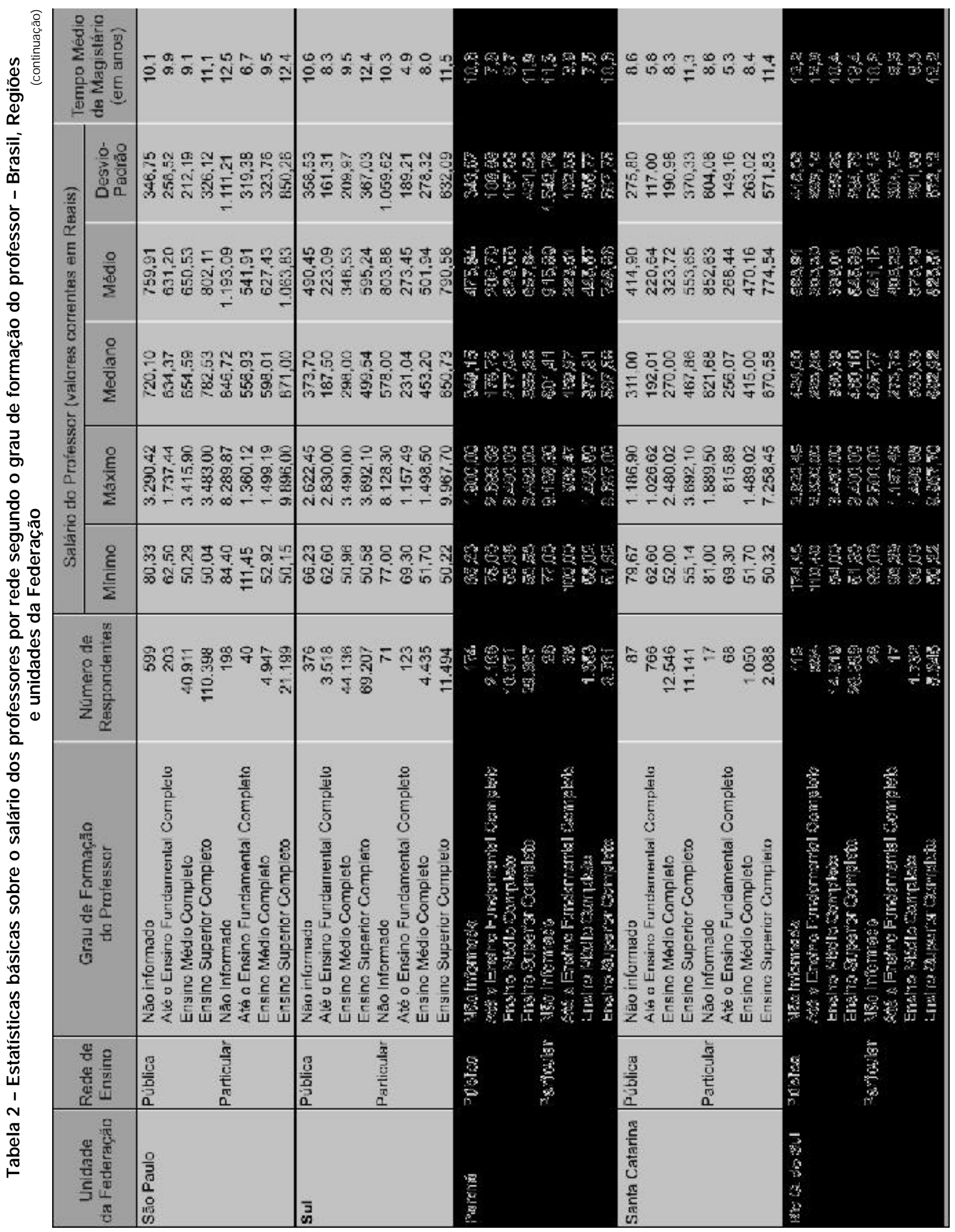




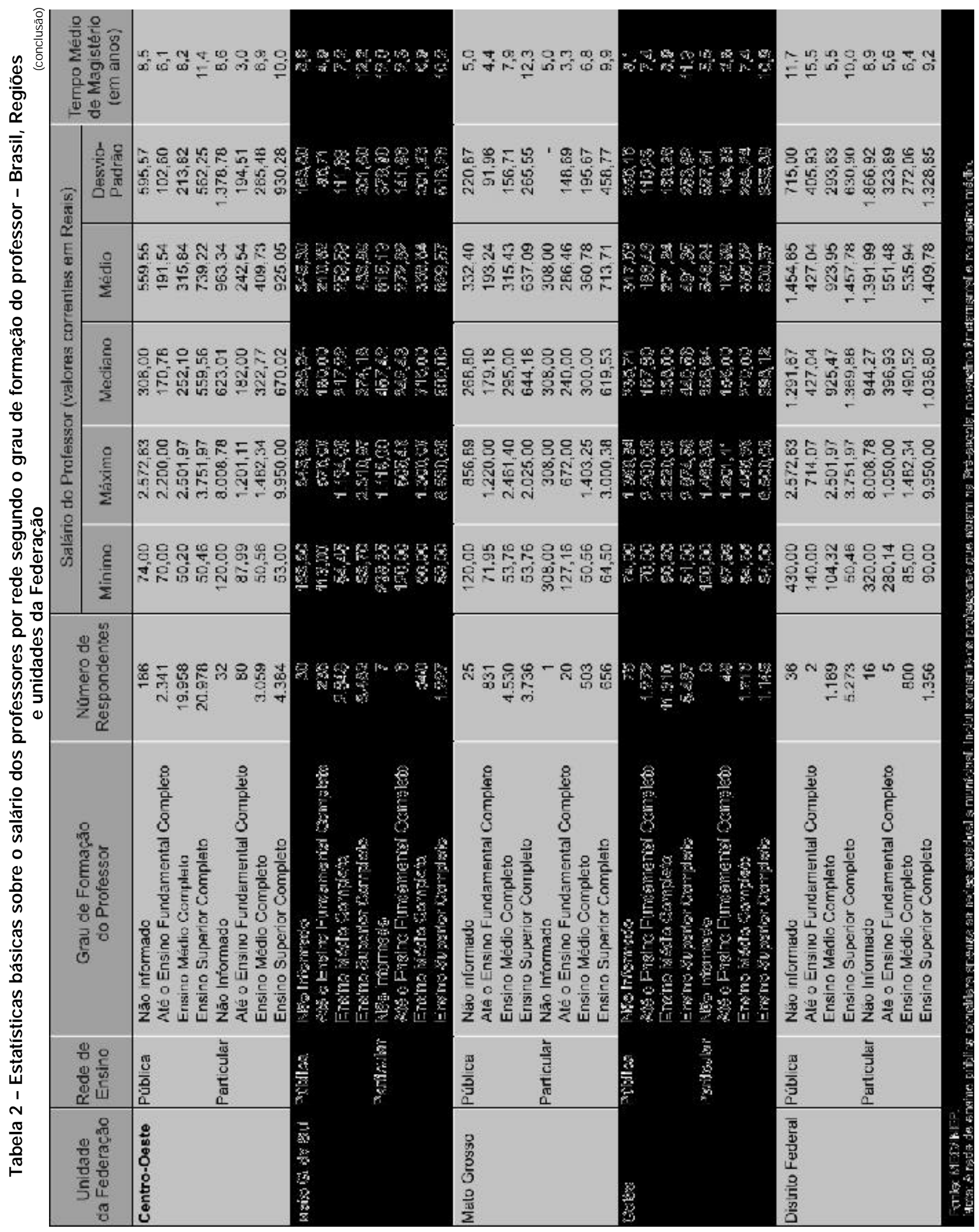

